FOAMING PROPERTIES OF WHEY PROTEIN ISOLATE AND $\lambda$-CARRAGEENAN MIXED SYSTEMS

A Thesis
Presented to
The Faculty of the Graduate School
At the University of Missouri
In Partial Fulfillment
Of the Requirements for the Degree
Master of Science
ByENGSHAN WANG
Dr. Bongkosh Vardhanabhuti, Thesis Supervisor
December 2013


The undersigned, appointed by the dean of the Graduate School, have examined the thesis entitled

\section{FOAMING PROPERTIES OF WHEY PROTEIN ISOLATE AND $\lambda$-CARRAGEENAN MIXED SYSTEMS}

Presented by ZHENGSHAN WANG, A candidate for the degree of Master of Science, And hereby certify that, in their opinion, it is worthy of acceptance.

Dr. Bongkosh Vardhanabhuti, Department of Food Science

Dr. Ingolf Gruen, Department of Food Science

Dr. Fu-Hung Hsieh, Department of Bioengineering 


\section{ACKNOWLEDGEMENTS}

I would like to thank my advisor, Dr. Vardhanabhuti, from the bottom of my heart, for her patience, generosity, and encouragement throughout my journey of pursuing my degree. Without her guidance and persistent helps, this thesis would not have been possible to be finished. I am also deeply grateful to my committee members, Dr. Gruen and Dr. Hsieh who gave their generous professional suggestions to make this study better. Nor should I forget Dr. O'Dell who gave me a lot of encouragements and stand an extraordinary example of dedication and hard working.

I would like to thank my colleagues in the lab, Sha Zhang, Yan Huan, Emily O'Chiu, Yue He, Sara Spoede, Madelyn Faust, Parichart Thamnarathip, Jun Xu and Emma Wicks who built a lovely environment for me to work in and lent me a hand whenever I needed. In particular, I would like to thank Sha, who helped me through the obstacles I encountered in my work.

Outside of the lab, many people helped me along the way. I would like to thank all the professors who gave great efforts for the enlightening classes. Special thanks to JoAnn Lewis, for her generous and constant helps; Dr. Aleksandr Jurkevic, and Harold Huff, for your insightful opinions and advices helped me through many technical difficulties.

I am certain there are people I left out whose services, helps and even words of wisdom benefitted my work, my career and my life, my sincerest thanks go to you. 


\section{TABLE OF CONTENTS}

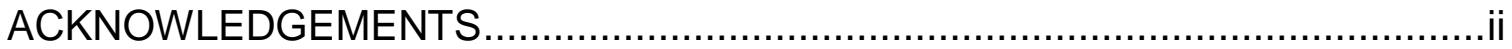

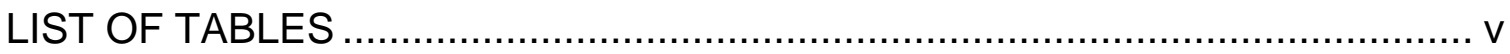

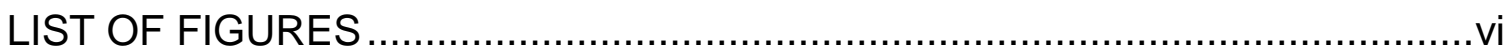

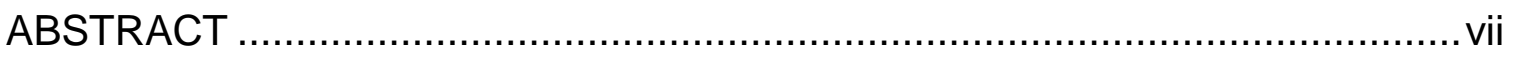

CHAPTER

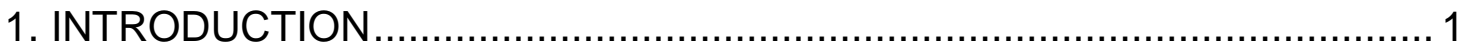

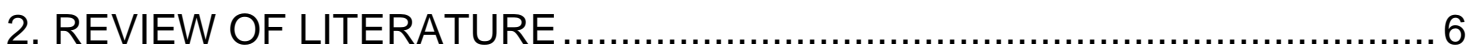

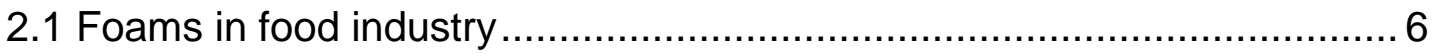

2.2 Whey protein and its foaming properties .................................. 15

2.3 Polysaccharide and its effects on foaming properties of protein ........... 18

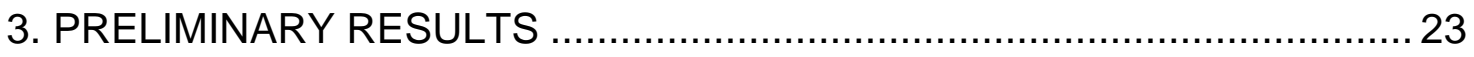

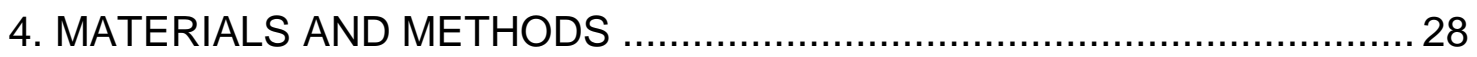

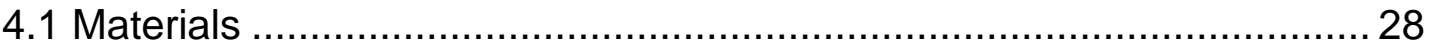

4.2 Protein and polysaccharide solutions........................................... 28

4.3 Foam formation ................................................................... 29

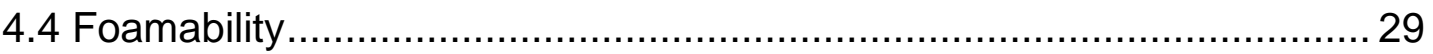

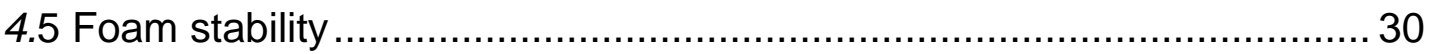

4.6 Zeta-potential and particle size measurements............................ 30

4.8 Confocal laser microscopic images analysis ............................... 31

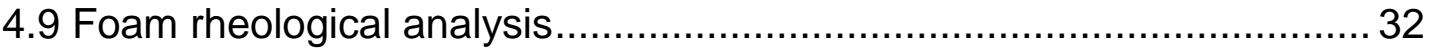

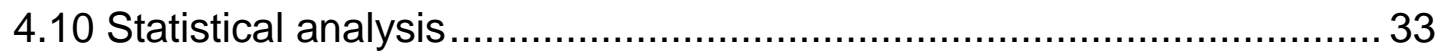




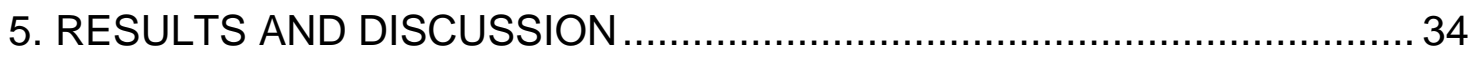

5.1 Effects of $\lambda$-carrageenan concentration on foaming properties .............. 34

$5.2 \mathrm{Effect}$ of $\mathrm{pH}$ of pre-foam solution on foaming properties ...................... 40

5.3 Zeta-potential and particle size of heated solution ............................... 45

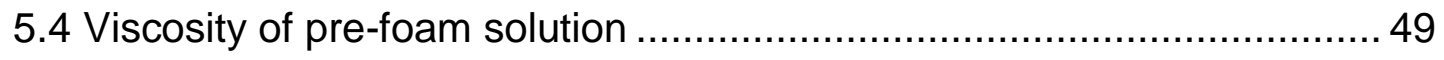

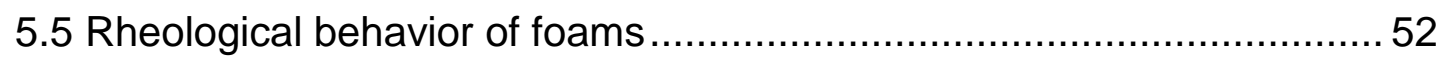

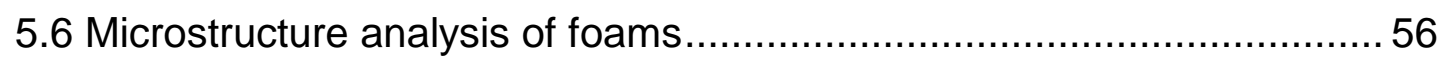

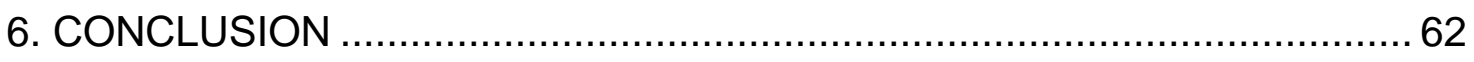

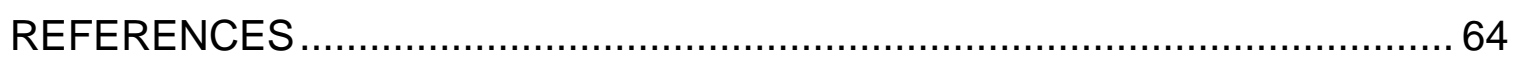

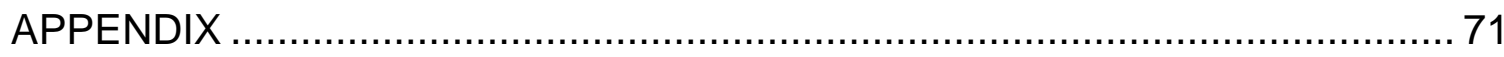




\section{LIST OF TABLES}

Table

Page

1. Preliminary results of foaming properties of SMP with WPI- $\lambda$ C systems.. 26

2. Viscosity of WPI- $\lambda \mathrm{C}$ mixed systems with different $\lambda \mathrm{C}$ concentration and different $\mathrm{pH}$..

3. Particle size and zeta-potential of $h-c p x$ and pWPI- $\lambda \mathrm{C}$ systems heated for 15 min under $85^{\circ} \mathrm{C}$ with different $\lambda \mathrm{C}$ concentrations and under different

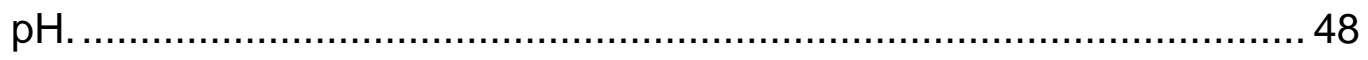

4. Initial bubble area and air phase fraction of three WPI- $\lambda$ C mixed systems based on image analysis 60 


\section{LIST OF FIGURES}

$\begin{array}{ll}\text { Figure } & \text { Page }\end{array}$

1. A schematic representation of the Plateau Border and thin liquid film in the

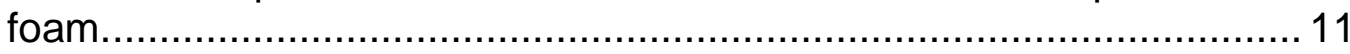

2. Foaming properties of pWPI- $\lambda \mathrm{C}$ and $\mathrm{h}-\mathrm{cpx}$ systems with $0.25 \% \lambda \mathrm{C}$ heated for different heating times under $85^{\circ} \mathrm{C}$ at $\mathrm{pH} 7$.

3. Overrun (a) and drainage $1 / 5$ life (b) of $\mathrm{WPI}$ and $\lambda \mathrm{C}$ mixed systems with different $\lambda \mathrm{C}$ concentrations at $\mathrm{pH} 7$.

4. Overrun (a) and drainage $1 / 5$ life (b) of WPI and $\lambda \mathrm{C}$ mixed systems with $0.25 \% \lambda \mathrm{C}$ at different $\mathrm{pH}$

5. Relations between foam properties and pre-foamed solution viscosity at $\mathrm{pH} 7$.

6. Amplitude sweep plot of WPI- $\lambda \mathrm{C}(\square) \mathrm{pWPI}-\lambda \mathrm{C}(\Delta) \mathrm{h}-\mathrm{cpx}(\diamond)$ with $0.25 \%$ $\lambda \mathrm{C}$ at $\mathrm{pH} 7$.

7. Frequency sweep plot of WPI- $\lambda \mathrm{C}(\square) \mathrm{pWPI}-\lambda \mathrm{C}(\Delta) \mathrm{h}-\mathrm{cpx}(\diamond)$ with $0.25 \%$

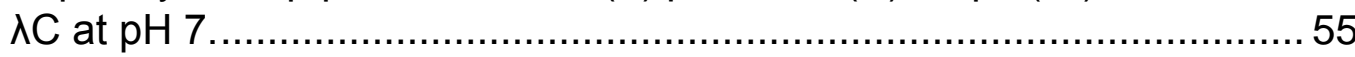

8. CLSM images of three WPI- $\lambda \mathrm{C}$ mixed systems with $0.25 \% \lambda \mathrm{C}$ at $\mathrm{pH} 7.0 \ldots$

9. Histograms of bubble area in the first CLSM images (10 min) of foams made by three systems 
FOAMING PROPERTIES OF WHEY PROTEIN ISOLATE AND $\lambda$ -

CARRAGEENAN MIXED SYSTEMS

\author{
Zhengshan Wang \\ Dr. Bongkosh Vardhanabhuti, Thesis Supervisor
}

ABSTRACT

Heating protein with polysaccharide under a net negative condition can induce the formation of soluble complex with improved functional properties. Studies on foaming properties of whey protein isolate (WPI) with polysaccharide mostly focused on the effects of polysaccharide on native WPI or heated WPI, while little has been done on heated WPI-polysaccharide soluble complex. The objective of our research was to investigate effects of different $\lambda$-carrageenan $(\lambda C)$ concentrations and $\mathrm{pH}$ on foaming properties of heated WPI and $\lambda \mathrm{C}$ soluble complex. Three WPI and $\lambda C$ systems were prepared: 1) heated WPI and $\lambda C$ soluble complex (h-cpx), (2) heated WPI with added $\lambda C(p W P I-\lambda C)$, and (3) unheated WPI with $\lambda C(\mathrm{WPI}-\lambda \mathrm{C})$. Foams were generated by beating the solution using a KitchenAid mixer. Foamability and foam stability were determined by measuring the foam overrun and drainage $1 / 5$ life, respectively. Foam rheological properties were determined using a Kinexus Pro Rheometer, while foam microstructures were visualized by confocal laser scanning microscopy (CLSM). For native WPI and $\lambda C$ mixed system, $\lambda C$ was needed in order for $5 \%$ 
WPI to form measurable foams. In all three WPI- $\lambda$ C systems at neutral $\mathrm{pH}$, increasing $\lambda C$ concentration led to improved foamability which increased with increasing $\lambda C$ concentration until a certain concentration before it decreased. Interestingly, despite their higher viscosity, both heated systems (pWPI- $\lambda \mathrm{C}$ and h-cpx) showed significantly better foamability and foam stability compared to WPI- $\lambda$ C. Results of rheological properties of foams made from treatments with $0.25 \% \lambda \mathrm{C}$ at neutral $\mathrm{pH}$ suggested that higher elasticity and viscous films were produced in $\mathrm{h}-\mathrm{cpx}$ and $\mathrm{pWPI}-\lambda \mathrm{C}$ systems corresponding to better foam stability. Heating WPI and $\lambda C$ together to form heated soluble complex resulted in thicker and viscoelastic interfacial film surrounding the air bubbles and thus better foam stability. Foam microstructure images indicated that foams produced form $\mathrm{h}$-cpx had thicker film surrounded the air bubbles, and consisted of smaller initial bubble area; more uniformed bubble size and slower destabilized. The effect of $\mathrm{pH}(6.2,6.5$ and 7.0$)$ was investigated in order to further confirm that stronger interactions between WPI and $\lambda C$ contributed to the improved foaming properties, since stronger electrostatic interactions formed at relative lower $\mathrm{pH}$. Foam stability was higher in h-cpx system at three $\mathrm{pH}$ level, especially under $\mathrm{pH} 6.2$ where strongest interactions formed compared with the other two $\mathrm{pH}$ levels. This study clearly demonstrated that foaming properties of WPI can be enhanced by interactions formed through adding anionic polysaccharide such as $\lambda C$. This can be applied to various dairy-based foams as well as new product development. 


\section{CHAPTER 1}

\section{INTRODUCTION}

Foams are colloidal systems formed by the agglomerations of disperse phase (gas) in the continuous phase (Damodaran and Paraf 1997). Proteins, as amphiphilic macromolecules, are considered as foaming agent because they have the ability to unfold and adsorb at the interfaces between the dispersed and continuous phases (Borcherding and others 2008; Tamm and others 2012) and to form a viscoelastic adsorbed layer (Wilde 2000a). Factors that affect foaming properties of proteins include intrinsic factors, such as molecular flexibility (Martin and others 2002; Engelhardt and others 2013) and environmental factors such as $\mathrm{pH}$, ionic strength, heating conditions and other ingredients (Zhu and Damodaran 1994; Phillips and others 2006; Phillips and others 1990; Phillips and others 2008; Raikos and others 2007; Clark and others 1994). Egg white protein is the traditional foaming agent for culinary foams; however, whey protein isolate (WPI) shows comparable foamability (overrun), allowing them to be considered as a potential replacement of egg white protein (Yang and Foegeding 2011; Berry and others 2009). However, the lack of foam stability, especially during baking, limits their use as foaming agents (Yang and Foegeding 2011; Foegeding and others 2006). Heating WPI to form soluble whey protein polymer (pWPI) has been shown to alter protein functional properties including foaming properties. Surface measurements showed that though pWPI adsorbed more slowly compared to 
native WPI, the interfacial elasticity (the major indicator of foam resistance to deformation) increased when $50 \%$ of native WPI was replaced with pWPI (Davis and Foegeding 2004).

Polysaccharides have been widely used in the food industry as stabilizer for emulsions and foams. They could modify protein functionalities through their electrostatic and hydrophobic interactions as well as hydrogen bonding with protein (Narchi and others 2009; Mishra and others 2001; Patino and Pilosof 2011). The interactions between protein and polysaccharide basically are mostly originated from electrostatic interactions between the oppositely charged regions (Schmitt and Turgeon 2011). Through affecting the extent of overall charge of protein, $\mathrm{pH}$ plays a significant role in the formation of electrostatically-driven complex. Under the $\mathrm{pH}$ lower than the isoelectric point $(\mathrm{pl})$ of protein, the positively charged protein can strongly bind to anionic polysaccharide which results in formation of both soluble and insoluble complexes (Ye 2008). However, even when both biopolymers have net negative charge (e.g., at neutral $\mathrm{pH}$ ), the homogeneous soluble complex can be formed by interactions between the positively charged patches of the protein and negatively charged anionic polysaccharide (Vardhanabhuti and Foegeding 2008; Vardhanabhuti and others 2009; Weinbreck and others 2004; Patino and Pilosof 2011; Zhang and others 2012; Zhang and others 2013).

Enhanced foaming properties by formation of protein and polysaccharide soluble complexes at $\mathrm{pH}$ higher than $\mathrm{pl}$ have been reported. Whey protein and polysaccharide soluble complex (e.g., WPC/pectin, WPI/guar gum, WPC/sodium 
alginate and $\mathrm{WPI} / \lambda \mathrm{C}$ ) at neutral $\mathrm{pH}$ have shown improved foaming stability due to their effect on increasing the viscosity of the aqueous phase which could limits the mobilization of aqueous phase around the bubbles and the ability to form thicker and more viscoelastic interfacial film (Mishra and others 2001; Perez and others 2009a; ErÇElebi and IbanoĞLu 2009). In addition, the effects of interactions between protein and polysaccharide on the interfacial properties of the film surrounding the dispersed phase also contribute to the enhanced foam stability. Surface pressure and surface dilatational elasticity at long adsorption time of WPC/ $\lambda \mathrm{C}$ soluble complex were higher compared to those of WPI alone (Perez and others 2009a). Baeza and others (2005) also reported increased surface pressure in $\beta-\lg / \lambda C$ system at $\mathrm{pH} 7$ that related to the interactions between the biopolymers. From the perspective of foamability, due to the thickening effect of polysaccharide, continuous phase with too high viscosity hinders the air incorporation process (ErÇElebi and IbanoĞLu 2009; Carp and others 2004) and may result in the reduced the protein diffusion rate at short adsorption time which limits the foamability (Baeza and others 2005). Properties of polysaccharide influence their interactions and thus the foaming properties of the soluble complexes. At the beginning of the adsorption, WPC/ $\lambda C$ soluble complex showed lower diffusion rate; however, due to high elastic of adsorbed film led by this soluble complex in the vicinity of the interface, the foamability of WPC/ $\lambda C$ was improved compared with pure WPC (Perez and others 2009a). In the presence of sodium alginate, increased diffusion rate was found which was 
probably associated with the interactions between sodium alginate with adsorbed protein (Perez and others 2009a).

Recently the functional properties of nanoparticles formed by heating protein and polysaccharide complexes at $\mathrm{pH}>\mathrm{pl}$ have been investigated. Zhang and others (2013) found that acid-induced gels formed by heated WPI-pectin soluble complex (formed by heating the biopolymers together at near neutral $\mathrm{pH}$ ) were firmer and had higher water holding capacity compared to gels formed by mixing pWPI and pectin (e.g., heated them separately then mixed). The gel microstructure showed smoother gel network with decreased pore size. It was proposed that unfolding of protein during heating allows more interactions between protein and polysaccharide via positively charged patches on the protein and oppositely charged polysaccharide as well as hydrophobic interactions leading to improved functional properties (De la Fuente and others 2004; Salminen and Weiss 2013). To the best of our knowledge, no study has been done on foaming properties of heated protein and polysaccharide soluble complex. With enhanced biopolymer interactions during heating, the resulting particles have a potential to have improved foaming properties.

The aim of this research was to investigate the foaming properties of heated WPI and lambda carrageenan $(\lambda C)$ soluble complex (formed by heating WPI and $\lambda \mathrm{C}$ together). $\lambda \mathrm{C}$ is a non-surface active polysaccharide containing high number of sulfate groups. Studies have shown improved foaming and interfacial properties of mixed protein and $\lambda C$ (no heated). This study systematically compared 1) unheated WPI with $\lambda \mathrm{C}(\mathrm{WPI}-\lambda \mathrm{C}), 2)$ heated WPI with added $\lambda \mathrm{C}$ 
(pWPI- $\lambda \mathrm{C}$ ), and 3 ) heated WPI and $\lambda \mathrm{C}$ soluble complex (h-cpx). The effects of $\lambda \mathrm{C}$ concentration and $\mathrm{pH}$ were studied. Foaming ability, foam stability and foam rheological properties were measured. Finally, the microstructures of foams were visualized by confocal laser scanning microscope and the bubble characteristics were analyzed. 


\section{CHAPTER 2}

\section{REVIEW OF LITERATURE}

\subsection{Foams in food industry}

\subsubsection{Introduction of foams}

Foams are colloidal systems that formed by the agglomerations of gas bubbles separated from each other by thin liquid films (Damodaran and Paraf 1997) and as thermodynamic unstable systems, foams facing destabilization process. Foams have attracted a lot of attentions from the food industry and culinary arts because of their unique mouth-feel and textural properties. In our daily life, a lot of food products have been developed based on foams, such as beer, ice cream, bread and cakes, soufflés, mousses, soft drinks, and marshmallow. The qualities of these products closely relate to the foam formation and foam stability. Many works have explored the mechanisms underlying foaming properties of food ingredients and different approaches to improve foaming properties have been studied (Bals and Kulozik 2003a; Hagolle and others 2000; Carp and others 2004; Davis and Foegeding 2007; Davis and others 2004; Davis and Foegeding 2004; Exerova and Kryglyakov 1998).

\subsubsection{Foam generation and evaluation of foam formation}

Continuous phase (water), dispersed phase (gas), surfactant and energy are usually the basic requirements for foam formation (Damodaran and Paraf 1997). Due to the thermodynamic instability between continuous and dispersed phase, 
surfactant acts as a bridge between two phases to reduce the interfacial tension. The surfactant agents used in foam formation should possess the following characteristics: firstly, they should have good adsorption ability at air-water interface during foam formation process; secondly, they should have the ability to allow rapid conformational changes and rearrangement at the air-water interface and be able to reduce the surface tension; finally, they should be able to form a viscoelastic interfacial film through molecular interactions in order to surround air bubbles and prevent the collapse or coalescence (Huppertz 2010).

Methods to incorporate air or gas within food structures can be classified into four categories: agitation/mechanical whipping, injection, super-saturation and fermentation (Jimenez-Junca and others 2011; Cmpbell and Mougeot 1999).

The agitation or whipping method is based on mechanical energy to introduce air into solution, includes stirring, whipping, and beating. These methods usually lead to large air bubbles initially and then the large bubbles could be disrupted into smaller ones by the shearing forces of the blades (Walstra 2003). Certain whipping speed and time is required to produce good foaming properties (Dickinson 1992). Usually higher speed leads to more air incorporation; however, too high whipping speed may result in local pressure fluctuation and rupture of air bubbles which impair foam formation.

In injection method, gases are injected into solution through very small nozzle to form foams. This method could control the amount of air that incorporated into the continuous phase. There are two formats of this method, injection-cold aeration and steam injection. The main difference between them is 
that the steam injection may lead to the increase in temperature of the solution during foam formation (Huppertz 2010). Steam injection is widely used in the preparation process of coffee beverage such as cappuccino, latté and mochaccino. Recently, a new technology using micro-porous membrane to make foam is under investigating where the dispersed phase is pressing into continuous phase through the pores on the membrane (Bals and Kulozik 2003a). This method provides a gently way to form foams and avoid additional denaturation of proteins occurred in agitation methods.

Super-saturation is another method that based on dissolving a gas in protein solution under certain pressure. The sudden release of pressure leads to the rapid reduces of gas solubility, thus the foams formed as a result (Huppertz 2010). Usually, this method is used in gas-containing beverages production.

Fermentation is a common bio-process which is accompanied by foam formation, especially in the solution of high foaming tendency, such as protein (Etoc and others 2006). Through the bioprocess of enzyme, such as yeast, bubbles can be generated under the controlled temperature, moisture, and time in the food structures. Bear and bread are the best examples for this method.

Overrun is an important concept expressing the formation of foam. This value represents the volume increase because the gas incorporated into the system (Campbell and Mougeot 1999). It can be expressed as \% overrun in the following equation:

$$
\% \text { overrun }=\frac{(\text { wt. } 100 \mathrm{~mL} \text { solution })-(\text { wt. } 100 \mathrm{~mL} \text { foam })}{\text { wt. } 100 \mathrm{~mL} \text { foam }} \times 100
$$


Foam capacity also can be measured through the volume of pre-formed solution and volume of foam after foam formation (Martínez and others 2011) using the following equation:

$$
\% \text { foam capacity }=\frac{(\text { foam volume })-(\text { solution volume })}{\text { solution volume }} \times 100
$$

\subsubsection{Foam destabilization}

Foams are thermodynamically unstable, which limits the shelf life and quality of foam-based food products, hence, most of the aerated foods, such as coffee drinks, have relatively short shelf life. Foam destabilization mechanisms have been extensively discussed and are commonly related to three aspects (drainage, disproportionation and coalescence) after foams formation.

Drainage caused by gravitational force and marginal regeneration (Dickinson 2003; Murray 2007; Halling 1981b). Because of the lower pressure of the Plateau borders (Fig. 1) compared to the adjoining film (Exerova and Kryglyakov 1998), "Plateau border suction" is formed. Therefore the liquid of the continuous phase drains from the adjoining film to the plateau border. Finally, under the force of gravitation, liquid will drain through the network of plateau border (Prud'homme and Khan 1995). The drainage can be downward or upward depending on the density difference between the continuous phase and dispersed phase.

Disproportionation (Ostwald ripening) process is another main reason for foam destabilization which is related to gas diffusion between bubbles and out to the atmosphere (Dutta and others 2004). Laplace pressure in the small bubble is greater than that in the big bubble, leading to the larger gas solubility (Yang and Foegeding 2011). Thus, the small bubble becomes smaller and finally disappears 
and larger bubble becomes larger, resulting in the decreasing in foam volume over time (Dutta and others 2004). From this view point, the more uniform size of the bubbles, the less the effect of disproportionation.

The last destabilization mechanism is coalescence which means the rupture of the thin liquid film of the two adjacent bubbles (Carrier and Colin 2003). In coalescence, two or more bubbles form one large bubble. This is an irreversible process; however, several technical approaches have been developed to make the foam more resistant to this process, such as improving the film characteristics by increasing viscosity and the interfacial elasticity, as well as increasing the repulsions between bubbles (Walstra 2003; Damodaran 2005; Wilde 2000a).

Foam stability is usually expressed as drainage $1 / 2$ life, which means the time necessary for half of the pre-foam mass to drain off the foams (Davis and Foegeding 2007; Davis and Foegeding 2004; Phillips and others 1990). Longer drainage $1 / 2$ life reflects better foam stability. Another way to determine foam stability is by measuring the change of foam volume at certain time after foam formation (Miquelim and others 2010). 


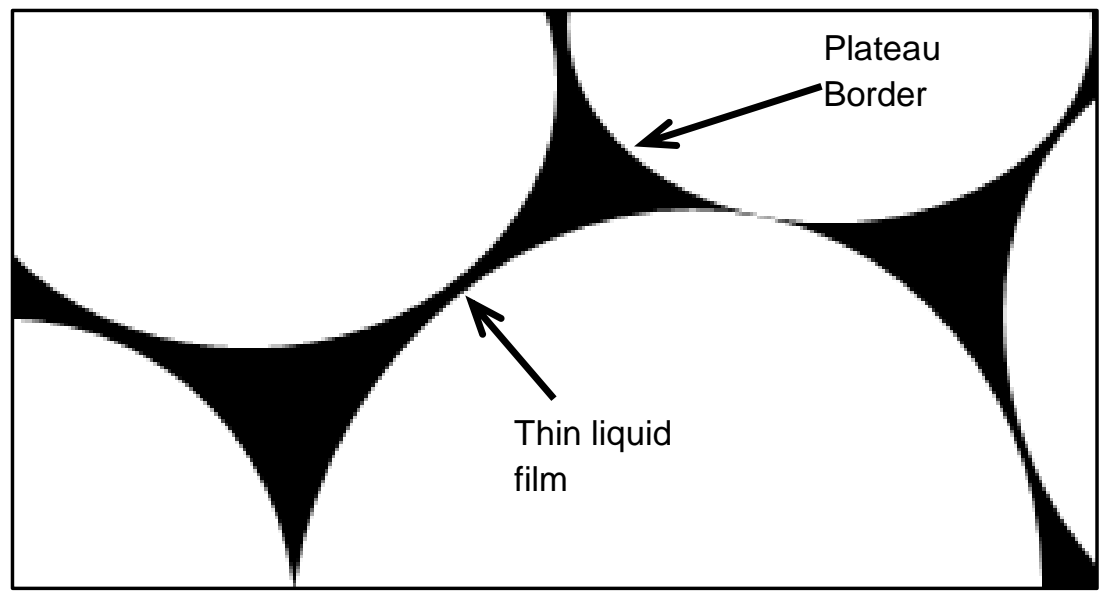

Figure 1. A schematic representation of the Plateau Border and thin liquid film in the foam. Dispersed phase-air bubbles (White); Continuous phase (Black). 


\subsubsection{Rheological properties of foam}

Understanding rheological properties of food has significant meaning for industry to design or choose the process equipment, such as mixing unit, pipelines and pumps (Luck and others 2002). Rheological properties of foams have gained a lot of attentions from researchers and industry because of revealing more characteristics of foam. Foams behave like elastic solid when the low stress being applied, while under high stress, they flow like a liquid (CohenAddad and others 1998; Höhler and Cohen-Addad 2005). The transition point from solid-like behavior to liquid behavior is called yield stress which depends on the characteristics of foams (overrun, bubble size distribution, liquid surface tension) (Rouyer and others 2005; Pernell and others 2002). Viscoelastic behavior, based on the measurements of elastic $G^{\prime}$ and loss $G^{\prime \prime}$ moduli, is another parameter to characterize the rheological behavior of foams. Dynamic rheology can be used to investigate the viscous and elastic components of foams. Strain oscillatory measurement is applied under small strain to get a linear viscoelastic region; while oscillatory frequency sweep is performed on foams within the linear viscoelastic region to determined viscoelastic behavior (JimenezJunca and others 2011). Studies indicated that the viscoelastic properties of the film surrounding the air bubble have close positive relationship with foaming stability (Halling 1981a; Nicorescu and others 2010; Allen and others 2008; Wilde 2000a). 


\subsubsection{Interfacial properties of pre-foam solution}

Dynamic interfacial properties of foaming agent plays important role in both foam formation and foam stability. Initial and significant step in foam formation is the adsorption of foaming agent to the air and water interface (Engelhardt and others 2013). Structure of foaming agent has great influence on the adsorption rate. Proteins have different structures (e.g., flexible to rigid/globular) exhibit different adsorption ability (Martin and others 2002). Different adsorption rates lead to different foamability (Wierenga and Gruppen 2010). Surfactant with larger particle size adsorb at the interface at a slower rate, thus having lower foamability (Rullier and others 2008). When proteins or surfactants adsorb at the interface the interfacial tension is reduced which assists foam formation (Davis and Foegeding 2007). Native proteins have been shown to decrease surface tension at a faster rate than the aggregated one (Rullier and others 2008). Surface tension is influenced by the extent of protein denaturation. At lower degree of denaturation (from $0 \%$ to $34 \%$ ), protein lowers surface tension, leading to a faster adsorption of partially unfolded whey proteins at the air-liquid interface. However, under high degree of denaturation (above 34\%), the opposite trend is found (Bals and Kulozik 2003a). Foam stability is mainly influenced by the formation of film at the interface. An increase in surface tension and surface elasticity at long term adsorption greatly improves foam stability (Perez and others 2009a; Baeza and others 2005). 


\subsubsection{Microstructure of foams}

Microstructures of foams have been used to visually reveal the geometric and dynamic characteristics of bubble in the foams. Foams can be analyzed by light microscope, and then imaged through CCD-camera (Bals and Kulozik 2003a). Confocal laser scanning microscopy (CLSM) is another tool for obtaining high-resolution optical images (Yang and Foegeding 2011).

Bubble size can be analyzed by different imaging system software based on the microscopy images, such as MetaMorph Imaging system (Yang and Foegeding 2011) and modular image analyzing software (Bals and Kulozik 2003a). The smaller initial bubble sizes contribute to the longer foam drainage life (Yang and Foegeding 2011). Similar results were also found in the study of different preheated skim milk solutions (Borcherding and others 2008). Bubble size distribution provides a detailed description of foams, and also influences foam stability because of its relation with coalescence and disproportionation. The narrower bubble size distribution leads to better foam stability. Lower gas diffusion was found in the more uniform bubble size system as well (Sarma Dshsr 1988). Yang and Foegeding (2011) described the bubble size distribution through histogram of bubble diameters and relative frequency. Comparing the bubble size distribution of foams at 0 min and 20 min after whipping, they found that a single peak distribution changed into a tri-modal pattern. This corresponded to the disproportionation process where gas transferred from small bubbles to large bubbles. 


\subsection{Whey protein and its foaming properties}

Whey liquid, containing $0.6 \%$ protein and $93 \%$ water, is a by-product from cheese making process or can be separated from milk (Foegeding and others 2002). The main compositions of whey protein are $\beta$-lactoglobulin ( $\beta-\lg , 65 \%), \alpha$ lactalbumin ( $\alpha-\mathrm{la}, 25 \%)$, and serum albumin (8\%). Whey protein can be denatured by heat (sustained high temperature above $72^{\circ} \mathrm{C}$ ).

The major commercial whey proteins are whey protein concentrate (WPC), whey protein isolate (WPI), and whey protein hydrolysate (WPH). WPC contains $29 \%$ to $89 \%$ protein by weight (most commonly available at $80 \%$ ), low level of fat and cholesterol, high levels of bioactive compounds and carbohydrates in the form of lactose. Rennet processed WPC contains a fraction of glycated proteins that known as glycomacropeptide (GMP) derived from chymosin hydrolysis of kappa casein (Perez and others 2009b). WPI contains more than $90 \%$ protein by weight. However some of bio-activated compounds are loss during the process. Both WPI and WPC have mild to slightly milky in taste. WPH are pre-digested and partially hydrolyzed which have less allergenic than other forms of whey protein (Foegeding and others 2002; Lee 1992). After hydrolysis process, the peptide bonds are cleaved therefore smaller peptide fractions are formed. WPH have various protein concentrations.

\subsubsection{Foaming properties of whey protein}

Functionality of whey proteins, such as gelation, emulsion and foaming, raises a lot of attentions in both academic and industry. Whey proteins, as amphiphilic macromolecules, are considered as foaming agent because they 
have the ability to unfold and adsorb at the interface between dispersed and continuous phases (Zayas 1997; Borcherding and others 2008; Tamm and others 2012; Wierenga and Gruppen 2010) and to form a viscoelastic adsorbed layer (Wilde 2000b). Foamability (as measured by the overrun) of whey proteins is comparable to egg white protein which allows them to be considered as a potential replacement of egg white protein (Yang and Foegeding 2011). The foaming properties or surface activities of proteins are closely related to the protein conformational properties, such as structure, size, shape, and amino-acid composition (Patino and Pilosof 2011) and external environment factors.

\subsubsection{Parameters influence foaming properties of protein}

External parameters, such as $\mathrm{pH}$, ionic strength, and heating condition directly affect protein structure and its interfacial properties, thus impact the foaming properties of whey protein (Zhu and Damodaran 1994; Phillips and others 2006; Phillips and others 1990; Phillips and others 2008; Raikos and others 2007; Clark and others 1994).

Thermal treatment has great influence on the structure and chemical characteristics of protein. On one hand, more exposed hydrophilic and hydrophobic groups, as a result of mild heating, connect the aqueous and nonaqueous phases, respectively, thus enhance the foaming properties (Zayas 1997; Zhu 1994). On the other hand, heating also leads to the formation of protein aggregates, which have lower adsorption rate and mobility to the interface, hence impair foaming properties (Rullier and others 2008). Bals and Kulozik (2003a) found that partially unfolded whey protein has higher surface activity and be able 
to build the stable interfacial liquid film to surround the air. Besides, high degree of denaturation through heating also results in high continuous phase viscosity which leads to the difficulty of incorporation of air, thus lower the foamability (Bals and Kulozik 2003a). Thermal treatment contributes to the enhancement of foam stability. The negative relationship between foaming temperature and the average foam bubble diameter was proved by the work of Borcherding and others (2008).

Altering $\mathrm{pH}$ can influence foaming properties of whey protein. It has been reported that better foam stability is achieved at $\mathrm{pH}$ close to $\mathrm{pl}$ due to the formation of thick and more elastic interfacial films under this condition (Halling 1981b; Zhang and others 2004; Borcherding and others 2009; Zayas 1997). On the other hand, conflicting results have been reported regarding the effect of $\mathrm{pH}$ on foamability. The foamability of protein can be maximized when $\mathrm{pH}$ is close to pl (Zhang and others 2004; Hailing and Walstra 1981), while higher overrun of milk protein was found with increasing $\mathrm{pH}$ in the range of $\mathrm{pH}>\mathrm{pl}$ (Borcherding and others 2009).

lonic strength plays an important role in determining foaming properties through affecting protein solubility and electrostatic properties. The overrun of $5 \%$ WPI had positive relation with $\mathrm{NaCl}$ concentration (from 0 to $1 \mathrm{M}$ ), and with the increasing of ionic strength, the stability showed a peak and then decreased (Mott and others 1999). Improvement in foamability and foam stability of $0.02 \%$ WPI was found under low $\mathrm{NaCl}$ concentration $(0.05 \mathrm{M})$ due to increased protein solubility, while at higher concentration foaming properties decreased because of 
the decreased solubility (ErÇElebi and IbanoĞLu 2009). Zhu and Damodaran (1994) reported that foam stability reached the maximum value in the presence of low concentration of $\mathrm{CaCl}_{2}(20 \mathrm{mM})$ and then decreased at higher $\mathrm{CaCl}_{2}$ concentration.

Other ingredients added in the pre-foam solution or during the foam formation also have great influence on foaming properties. Addition of sucrose resulted in decreased initial bubble size of WPI foam, which was related to higher foam stability and lowered air phase fraction (Yang and Foegeding 2011). Similar result was also found by Raikos and others (2007) that sugar decreased the overrun of protein. Herceg and others (2007) reported that addition of glucose, starch and inulin enhanced foam stability compared with whey protein isolate alone, while the effects on foamability were different. Addition of glucose showed better foam expansion than control group, while starch and inulin addition had lower foamability. Lipid is naturally presented in food sources. However, fat acts as an antifoaming agent during fermentation and whipping of foams (Clark and others 1994; Dubreil and others 1997). Adding lysozyme (0.5\%) into $\beta$-lg $(2.5 \%)$ could reduce the time required to reach maximum overrun and increased foam stability and heating stability.

\subsection{Polysaccharide and its effects on foaming properties of protein}

Polysaccharides are high molecular weight carbohydrate molecules of large amount of monosaccharide units joined together by glycosidic bonds. They have various molecular structures from linear to highly branched. The structures of these macromolecules make great contributions to the distinct functional 
properties of polysaccharides. Due to their unique functional properties, such as stabilization, thicken agent, they have been used to modify protein's function through their electrostatic and hydrophobic interactions with protein (Narchi and others 2009; Mishra and others 2001; Patino and Pilosof 2011).

\subsubsection{Protein and polysaccharide interactions}

The electrostatic interactions are the main driven force for the protein and polysaccharide interactions, which depend, to a great extent, on the $\mathrm{pH}$ of the medium. When $\mathrm{pH}$ is lower than protein's $\mathrm{pl}$, insoluble protein-polysaccharide complex may form due to charge neutralization through interactions between positively charged protein and anionic polysaccharide, while soluble proteinpolysaccharide complex can be obtained when protein continue bind with more anionic polysaccharide that make it overall negative charged. When $\mathrm{pH}$ is higher than the pl of the protein, the interaction could still occur because negatively charged polysaccharides could attach the positive patches on the protein (Vardhanabhuti and others 2009; Vardhanabhuti and Foegeding 2008; Patino and Pilosof 2011; Weinbreck and others 2004). Other than $\mathrm{pH}$, heat treatment also plays an important role in the formation of protein and polysaccharide complex. Heating leads to the changes of protein's structure which promotes the formation of heated soluble complex. More positive regions of the protein are exposed during unfolding, which results in more available domains for the interactions with anionic polysaccharide (Zhang and others 2012; Salminen and Weiss 2013). Protein and polysaccharide soluble complexes exhibit superior 
functional properties such as gelling properties, foaming and emulsion stability (Zhang and others 2013; Dickinson 2008).

\subsubsection{Effects of polysaccharide on the foaming and interfacial properties of protein}

Addition of polysaccharide could increase the viscosity of continuous phase, which directly increase foam stability by decreasing drainage. In addition, interactions between protein and polysaccharide can affect interfacial properties, hence altering foaming properties of protein.

The foamability and foam stability of protein depend on both the nature of polysaccharides and the biopolymer ratio. In the presence of polysaccharides, foamability of protein generally depends on the biopolymer ratio. With the addition of high amount of polysaccharides, the viscosity of the continuous phase significantly increases, which hinders the air incorporation process in foam formation. For example, $0.02 \%$ WPI added with $0.01 \%$ or $0.5 \%$ guar gum exhibited significantly reduced foamability compared with WPI alone (ErÇElebi and IbanoĞLu 2009). Similar results were reported by Carp and others (2001) that foamability of $2 \%$ soy protein decreased when $>0.05 \%$ xanthan was added. However, some studies indicated that appropriate polysaccharide ratio enhanced foamability. Addition of $0.05 \%$ xanthan, WPI (5\%) solution produced better foamability compared to that in an absence of xanthan (Mott and others 1999). Martínez and others (2011) found that foamability of soy protein (2\%) increased by adding $0.3 \%$ hydroxypropyl methyl cellulose. Typically, foam stability could be greatly improved by polysaccharide due to the increased viscosity of the 
continuous phase and the formation of thicker and more viscoelastic interfacial film (Carp and others 2001; Mishra and others 2001; Mott and others 1999;

Perez and others 2009a; ErÇElebi and IbanoĞLu 2009). Interfacial properties at short-term adsorption of protein, which are related to the foamability, could be affected by polysaccharides. In the foam formation process, protein has to diffuse to the interface so they form a film around the air bubbles. Higher diffusion rate and increased interfacial elasticity at short adsorption time could promote foam formation. Perez and others (2009a) reported that foamability were higher in both WPC/sodium alginate compared with pure WPC, which corresponded to higher diffusion rate of protein to the interface and the higher surface elasticity at the beginning of adsorption. The promoted protein adsorption rate was also found in both $\beta$-LG-xanthan and WPC-xanthan systems (Perez and others 2010). However, some studies also reported the protein diffusion rate could be slow down when adding different polysaccharide. Perez and others (2009a) found the decreased diffusion rate in WPC/ $\lambda \mathrm{C}$ system which better foamability than native WPC could contributes to the higher elastic film formed by the attractive interactions between protein and $\lambda \mathrm{C}$. With addition of $\lambda \mathrm{C}$, reduction of diffusion rate also was found in $\beta$-la with $3 \%$ and $5 \%$ hydrolysis degree, but due to the interactions of protein and $\lambda \mathrm{C}$, the protein could rearrangement at interface faster and form more elastic film surround bubble (Perez and others 2012). Foam stability has positive relation with the surface pressure and surface dilatation elasticity at long-term adsorption. Perez and others (2009a) reported that the improvements of foam stability were found in both WPC/PS and WPI/PS systems 
due to the increasing surface pressure and surface dilatational elasticity at long adsorption time. Baeza and others (2005) also indicated the increase of surface pressure of $\beta$-la (2\%) and xanthan or $\lambda \mathrm{C}$ mixed system $(\mathrm{pH} 7)$ at long-term adsorption (1000S).

In summary, the interactions between protein and polysaccharides may influence the viscosity of solution and alter the interfacial properties and characterizations of air-water interface. Heated soluble complexes with higher degree of interactions between biopolymers are expected to have better foam properties. This is especially important for whey proteins since improved foam stability may increase their potential in becoming important foaming agents. Only a small number of studies have investigated the foaming properties of whey protein and polysaccharide mixed systems. To the best of our knowledge, no study has been done on heated whey protein and polysaccharide complex formed at $\mathrm{pH}>\mathrm{pl}$ where their interactions can be enhanced during heating. The overall goal of this thesis was to systematically investigate the effect of polysaccharide and heating on foaming properties of whey protein, particularly at the conditions where they can form heated protein-polysaccharide soluble complex. Foaming properties were assessed by measurements of overrun, drainage $1 / 5$ life, and foam rheological properties. The effect of $\mathrm{pH}$ was studied to understand the importance of the interactions at $\mathrm{pH}>\mathrm{pl}$ of the proteins. Microstructure of foams was determined by confocal laser scanning microscopy in order to better understand foam destabilization. 


\section{CHAPTER 3}

\section{PRELIMINARY RESULTS}

In systematically investigated the effect of heating and polysaccharide on foaming properties of WPI, we divided mixed WPI and lambda carrageenan $(\lambda C)$ into three systems: mixed native WPI and $\lambda C$, and heated WPI- $\lambda C$ soluble complex (heated together). The goal of the preliminary experiments was to determine whether there was any difference among the three systems. We also thought of the application of the study, so we first include skim milk powder (SMP) with the three WPI and $\lambda C$ systems. SMP was included since it can be applied in coffee beverages. The total protein content of pre-foam solutions was $5 \%$ (5\% SMP or $2.5 \% \mathrm{SM}+2.5 \% \mathrm{WPI}$ ) and polysaccharide $(\lambda \mathrm{C})$ concentration was 0.05\%. "pWPI" stands for heated WPI, "h-cpx" stands for heated soluble complex which means heating protein and $\lambda C$ together and "pWPI- $\lambda C$ " means heated WPI and mixed with polysaccharide. Heating treatment was conducted under $85{ }^{\circ} \mathrm{C}$ temperature controlled water bath for $15 \mathrm{~min}$. As shown in Table 1, foamability of SMP increased by addition of native WPI or heated WPI (pWPI) and decreased with addition of $\lambda C$. However, in the presence of $\lambda C$, the foam stability of SMP was greatly improved. Interestingly, the foam produced from the treatments of SMP+h-cpx and SMP+pWPI- $\lambda C$ exhibited better foam stability than all other groups and foamability just slight lower (9.3\%) than the best overrun obtained in 
SM+pWPI treatment. The results here indicated that formation of heated soluble complex could provide better stability for the systems and maintained foamability as well. However, we realized that SMP also contained casein which would make it very challenging to determine the mechanisms of how heated WPI- $\lambda \mathrm{C}$ soluble complex influenced foaming properties of protein. Since the benefit of pWPI- $\lambda \mathrm{C}$ and h-cpx already been shown and WPI had higher protein concentration and purity, WPI and $\lambda \mathrm{C}$ mixed systems were used for the further experiments.

In selecting total protein concentration, we also experimented with high protein content. WPI- $\lambda \mathrm{C}$ mixed systems containing $10 \% \mathrm{w} / \mathrm{w}$ total protein was used in the preliminary experiment. However, high protein concentration led to gelation in the process of making heated soluble complex. So the protein concentration was selected at $5 \%$ which provided enough protein to foam and not induced gelation. Heat treatment is an important step in formation of heated soluble complex and therefore the effect of heating time on the foaming properties of WPI- $\lambda \mathrm{C}$ mixed systems was investigated as well. Results in Fig. $2 \mathrm{a}$ shows that overrun of both $5 \% \mathrm{pWPI}-\lambda \mathrm{C}$ and $\mathrm{h}-\mathrm{cpx}$ system decreased with increasing heating time. This was probably due to the increased continuous phase viscosity which prevented the air incorporation. Fig. $2 b$ shows the influence of heating time on the foam stability. Both pWPI- $\lambda \mathrm{C}$ and $\mathrm{h}-\mathrm{cpx}$ systems reached maximum foam stability under 15 min heating. The drainage $1 / 5$ life of pWPI- $\lambda \mathrm{C}$ under $15 \mathrm{~min}$ and $30 \mathrm{~min}$ increased by $33.9 \%$ and $17.5 \%$, respectively, compared with that at 5 min heating, while in h-cpx system, increased by $56.6 \%$ and $50.6 \%$ respectively. Comparison of foam stability between pWPI- $\lambda \mathrm{C}$ and $\mathrm{h}-$ 
cpx systems shows that $\mathrm{h}-\mathrm{cpx}$ treatment had better foam stability under $15 \mathrm{~min}$ and 30 min heating which might be contributed to the formation of heated soluble complex. Taking both foamability and foam stability into consideration, 15 min of heating was applied to form heated soluble complex in the following experiments. 
Table 1. Preliminary results of foaming properties of SMP with WPI- $\lambda$ C systems.

\begin{tabular}{lllll}
\hline \multirow{2}{*}{ Treatment } & \multicolumn{3}{c}{ Drainage (g) of foam over time } & \multirow{2}{*}{ Overrun (\%) } \\
\cline { 2 - 4 } & $60 \mathrm{~min}$ & $90 \mathrm{~min}$ & $120 \mathrm{~min}$ & \\
\hline $\mathrm{SMP}$ & 10.47 & 18.57 & 23.07 & 917 \\
$\mathrm{SMP}+\mathrm{WPI}$ & 12.73 & 20.71 & 24.30 & 1177 \\
$\mathrm{SMP}+\mathrm{pWPI}$ & 11.75 & 19.46 & 23.76 & 1178 \\
$\mathrm{SMP}+\lambda \mathrm{C}$ & 2.50 & 9.20 & 14.30 & 778 \\
$\mathrm{SMP}+\mathrm{WPI}-\lambda \mathrm{C}$ & 5.45 & 12.65 & 18.00 & 1092 \\
$\mathrm{SMP}+\mathrm{pWPI}-\lambda \mathrm{C}$ & 0.75 & 7.95 & 14.4 & 1068 \\
$\mathrm{SMP}+\mathrm{h}-\mathrm{cpx}$ & 0.77 & 8.97 & 13.00 & 1068 \\
\hline
\end{tabular}



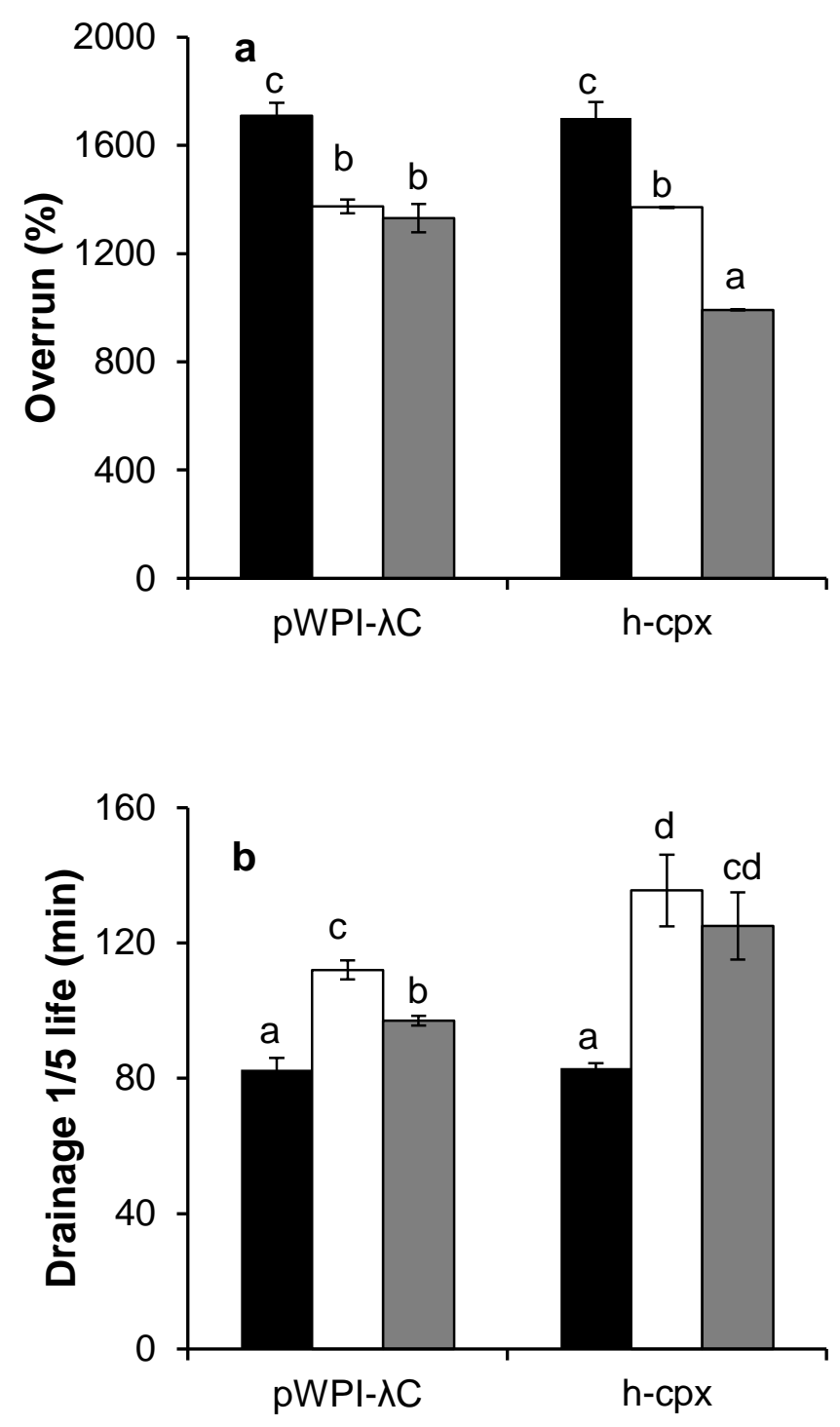

Figure 2. Foaming properties of $5 \% \mathrm{pWPI}-\lambda \mathrm{C}$ and h-cpx systems with $0.25 \% \lambda \mathrm{C}$ heated for $5 \mathrm{~min}$ (black), $15 \mathrm{~min}$ (white) and $30 \mathrm{~min}$ (gray) under $85^{\circ} \mathrm{C}$ at $\mathrm{pH}$ 7. (a) Foamability (b) Foam stability. 


\section{CHAPTER 4}

\section{MATERIALS AND METHODS}

\subsection{Materials}

Whey protein isolate (WPI, Bipro) was kindly provided by Davisco Foods International, Inc. (Le Sueur, MN). WPI consisted of $97.9 \%$ protein (dry weight basis), $2.1 \%$ ash, and $0.3 \%$ fat (dry weight basis). Lambda-Carrageenan $(\lambda C)$ (Viscarin GP 209 F) was obtained from FMC BioPolymer (Philadelphia, PA). Rhodamine B was obtained from Acros Organics (Fair Lawn, NJ). Deionized (DI) water with a minimum of $18.2 \mathrm{M} \Omega-\mathrm{cm}$ was used to prepare all solutions.

\subsection{Protein and polysaccharide solutions}

Three different systems were designed to investigate the WPI and $\lambda \mathrm{C}$ systems: 1) unheated WPI with $\lambda \mathrm{C}(\mathrm{WPI}-\lambda \mathrm{C}), 2)$ heated WPI with added $\lambda \mathrm{C}$ (pWPI- $\lambda \mathrm{C})$, and 3 ) heated WPI and $\lambda \mathrm{C}$ soluble complex (h-cpx).

WPI stock solution ( $8 \% \mathrm{w} / \mathrm{w}$ ) was prepared by slowly dissolving the protein powder into DI water with continuous stirring for at least $2 \mathrm{~h}$ at room temperature $\left(22 \pm 2{ }^{\circ} \mathrm{C}\right)$. Polysaccharide stock solution $(3.3 \% \mathrm{w} / \mathrm{w})$ was prepared by slowly adding $\lambda \mathrm{C}$ into $\mathrm{DI}$ water at $65^{\circ} \mathrm{C}$ and under constant stirring for $2 \mathrm{~h}$ using a magnetic stir plate. The stock solutions were stored at $4{ }^{\circ} \mathrm{C}$ overnight to allow for full hydration.

For native WPI and $\lambda \mathrm{C}(\mathrm{WPI}-\lambda \mathrm{C})$ system, appropriate amount of unheated WPI stock solution was mixed with appropriate amount of $\lambda \mathrm{C}$ stock solution and 
the $\mathrm{pH}$ and weight were adjusted such that the mixtures contained $5 \% \mathrm{w} / \mathrm{w}$ protein and 0 to $0.25 \% \mathrm{w} / \mathrm{w} \lambda \mathrm{C}$ and $\mathrm{pH} 6.2,6.5$ and 7.0 .

For heated WPI with added $\lambda C(\mathrm{pWPI}-\lambda \mathrm{C})$ systems, WPI polymer was prepared in the first step. WPI stock solution was diluted with DI water to reach the initial protein concentration of $6 \% \mathrm{w} / \mathrm{w}$ and adjusted $\mathrm{pH}$ to $6.2,6.5$ and 7.0 , then heated at $85^{\circ} \mathrm{C}$ for $15 \mathrm{~min}$ and cooled. The appropriate amount of $\lambda \mathrm{C}$ was added and $\mathrm{pH}$ was re-adjusted. Finally, DI water was added such that the samples contained $5 \%(\mathrm{w} / \mathrm{w})$ protein and $0-0.25 \% \lambda C$.

Heated soluble WPI/ $\lambda \mathrm{C}$ complex (h-cpx) was prepared by mixing WPI and $\lambda \mathrm{C}$ stock solutions at appropriate amount and adjusting the $\mathrm{pH}$ to $6.2,6.5$ and 7.0. DI water was added so that the solutions contained $6 \% \mathrm{w} / \mathrm{w}$ protein and $0.06 \%$ to $0.3 \% \mathrm{w} / \mathrm{w} \lambda \mathrm{C}$. The mixed solution was gently stirred for $30 \mathrm{~min}$ at room temperature before heating in a controlled temperature water bath at $85^{\circ} \mathrm{C}$ for 15 min. Heated samples were immediately cooled and DI water was added to obtain the final concentration of $5 \% \mathrm{w} / \mathrm{w}$ protein and $0.05 \%$ to $0.25 \% \mathrm{w} / \mathrm{w} \lambda \mathrm{C}$.

\subsection{Foam formation}

Foams were generated by a Kitchen Aid Ultra Power Mixer (Kitchen Aid, St. Joseph, Michigan). Solutions (50 g) were placed into a $4.3 \mathrm{~L}$ Kitchen Aid stainless steel bowl and whipped by rotating flat beater at speed 8 (equal to 225 planetary rpm and 737 beater rpm) for $20 \mathrm{~min}$.

\subsection{Foamability}

Foamability was determined by measuring the overrun (Phillips and others 1987). The foams were gently taken out immediately after whipping and placed 
into a standard weigh boat $(100 \mathrm{~mL})$, leveled using a rubber spatula, and weighed. The process was repeated at least 4 times per foam. The average weight was used in the following equation to calculate the overrun:

$$
\% \text { Overrun }=\frac{(w t .100 \mathrm{~mL} \text { solution }-w t .100 \mathrm{~mL} \text { foam })}{w t .100 \mathrm{~mL} \text { foam }} \times 100
$$

Average overrun of each treatment was obtained through two replications.

\subsection{Foam stability}

As described by Davis and Foegeding (Davis and Foegeding 2007), drainage time, representing foam stability, was measured immediately after foam formation. The mixing bowl with a $6 \mathrm{~mm}$ diameter hole in the bottom was used for stability measurements. The time necessary for one fifth of the pre-foam mass to drain through the hole was recorded as fifth life. Longer fifth life indicated greater foam stability. Each treatment was repeated two times.

\subsection{Zeta-potential and particle size measurements}

Zetasizer Nano ZS (Malvern Instruments Ltd., Worcestershire, UK) equipped with $633 \mathrm{~nm}$ laser and $173^{\circ}$ detection optics was used to measure the zetapotential and particle size of pre-foam solutions. The zeta-potential was calculated based on the electrophoretic mobility using the Henry equation. The pre-foam solution was diluted by DI water to $0.3 \%$ protein concentration in order to measure particle size. The experiments were performed at room temperature $\left(25 \pm 0.2^{\circ} \mathrm{C}\right)$. Data was collected over 3 sequential readings and each measurement was carried out at least twice.

\subsection{Viscosity measurement}


The viscosity of pre-foam solutions was measured over a range of shear rates $\left(0.5 \mathrm{~S}^{-1}\right.$ to $\left.400 \mathrm{~S}^{-1}\right)$ by a Kinexus Rheometer (Malvern Instruments Ltd., Worcestershire, United Kingdom) using cone and plate geometry with a $0.05 \mathrm{~mm}$ gap. The angle and diameter of the cone geometry were $4^{\circ}$ and $40 \mathrm{~mm}$. Two replicates were performed at $25^{\circ} \mathrm{C}$.

\subsection{Confocal laser microscopic images analysis}

Foam microstructure was visualized by a Zeiss LSM 510 META confocal laser scanning microscope (Carl Zeiss, Jena, Germany). Rhodamine B, as a specific dye for protein, was added into each sample prior to foam formation (0.2 $\mathrm{mL}$ of $0.1 \% \mathrm{w} / \mathrm{w}$ for $1 \mathrm{~g}$ protein). After whipping (as previously described), a small amount of foam was gently loaded into a single-welled microscope slides (with 1$1.2 \mathrm{~mm}$ concavity) covered with a \# 1.5 coverslip and immediately imaged. An argon laser excited samples at $543 \mathrm{~nm}$, and the detection bandwidth was set from 565 to $615 \mathrm{~nm}$. Plan-Neofluar 10 x/0.3 objective lenses, BP 565-165 IR filter and $80 \mu \mathrm{m}$ pinhole were applied. Digital image files were acquired in 1024 pixels $\times 1024$ pixels. The temperature was controlled at room temperature $(25 \pm$ $\left.2{ }^{\circ} \mathrm{C}\right)$.

Time lapse mode, which scans the same position of a slide over a certain time period, was used to collect images for all treatments. The first image was collected starting from 10 min after foam formation (to provide enough time to set up the slide) and subsequent images were taken every $30 \mathrm{~s}$ for 15 min. Images at $10,13,16,19$ and 22 min of each treatment were selected to represent the destabilization of foam over time. 
In order to analyze the images, a slide of each foam sample was prepared as previously described. Three random positions (at the same depth of $123 \mu \mathrm{m}$ ) in each slide were rotationally scanned by CLSM at 10,13, 16, 19 and 22 min after foam formation. The imaging time between each position was less than $20 \mathrm{~s}$. Image analysis results were shown as the average values of each treatment. MetaMorph Imaging System Software (Molecular Devices Corporation, Pennsylvania, USA) was used to analyze the bubbles (Yang and Foegeding 2011). The same threshold (low value: 0 ; high value: 13) was applied to all images to make bubbles stand out against the background. "Cut" tool was used to separate the attached bubbles, while "Join" tool was used to outline the bubbles and to fill the broken center. Partial bubbles in the upper and right edges of the image were excluded from the analysis. Bubble size distribution was plotted according to the area of each bubble that was obtained through image analysis. Results of initial bubble area and air phase fraction were reported as the average of three positions for each sample.

\subsection{Foam rheological analysis}

A Kinexus Rheometer (Malvern Instruments Ltd., Worcestershire, United Kingdom) in oscillatory mode equipped with serrated plate-and-plate geometry (40 mm) was used to measure foam viscoelastic properties. Immediately after whipping, foams were gently placed in the center of the lower plate and the upper geometry was gently descended to a gap of $2 \mathrm{~mm}$. Any excess foam was carefully removed, and foams were allowed to stabilize for $1 \mathrm{~min}$ before testing. Logarithmic amplitude sweep in the range of $0.001-10 \%$ strain at a frequency of 
$0.5 \mathrm{~Hz}$ and $25^{\circ} \mathrm{C}$ was applied to obtain the linear viscoelastic region (LVR). Frequency sweep from 0.1 to $10 \mathrm{~Hz}$ was performed at $0.5 \%$ strain and $25^{\circ} \mathrm{C}$. Elastic $\left(G^{\prime}\right)$ and viscous $\left(G^{\prime \prime}\right)$ moduli were recorded. All measurements were performed under solvent trap setting to avoid drying of the foams.

\subsection{Statistical analysis}

All Statistical analyses were performed using SPSS software (SPSS Inc., Ver. 20, Chicago, IL). One-way ANOVA was conducted to compare the mean values and determine the differences between treatments. Significant differences were obtained by Duncan's test at a significance level of 0.05 . 


\section{CHAPTER 5}

\section{RESULTS AND DISCUSSION}

\subsection{Effects of $\lambda$-carrageenan concentration on foaming properties}

\section{Overrun}

Foamability was assessed by measuring the overrun of foams. The effects of $\lambda C$ concentrations were observed in three mixed WPI and $\lambda C$ systems. Note that the terms "WPI- $\lambda$ C" refers to native WPI with added $\lambda$-carrageenan, "pWPI" refers to heated WPI or WPI polymer, "pWPI- $\lambda C$ " refers to WPI polymer with added $\lambda$ carrageenan and "h-cpx" refers to heated soluble WPI and $\lambda$-carrageenan complex. As shown in Figure $3 a, 5 \%$ native WPI solution without $\lambda \mathrm{C}$ did not produce measureable foam. With the aid of $0.05 \% \lambda \mathrm{C}$, the measureable foams were formed. Increasing $\lambda C$ concentration led to increased overrun which peaked at $0.15 \% \lambda C$ and the overrun then decreased at higher $\lambda C$ concentrations. The effect of $\lambda C$ on foaming properties of native whey protein concentrate (WPC) was reported by Perez and others (2009a). Addition of $0.1 \% \mathrm{w} / \mathrm{w} \lambda \mathrm{C}$ was necessary to produce satisfactory foam of WPC $(1 \% \mathrm{w} / \mathrm{w})$; however, increased $\lambda C$ concentration did not affect foamability. The effect of polysaccharide on protein foam could be explained by the interfacial characteristics of the adsorbed film. The dynamic properties of the adsorbed film showed slower diffusion rate of the protein and lowered interfacial dilatational elasticity in the presence of $\lambda C$ at short adsorption time. These were due to the weak interactions between the 
biopolymers and the formation of WPI- $\lambda$ C complex (Perez and others 2009a). The positive effect of $\lambda C$ on foamability was due to increased elasticity of the adsorbed film as shown by higher interfacial dilatational elasticity at longer absorption time. Higher elastic film from WPC- $\lambda$ C interactions allowed the foams to be stable and resisted destabilization right after foaming. The effect of $\lambda \mathrm{C}$ concentration on foamability of native WPI was similar to that shown by Mott and others (1999). Addition of $0.05 \%$ xanthan gum improved the overrun of $1,2.5$, and $5 \%$ WPI foams but foamability decreased at higher xanthan concentration. It was proposed that a certain level of viscosity produces better overrun but higher viscosity at increased xanthan concentrations was proposed to be the reason for decreased foamability.

Heated WPI without $\lambda \mathrm{C}$ (pWPI) produced measurable foam (Fig. 3a). Heat treatment can induce the changes in the secondary structure and tertiary structure of proteins which affect protein adsorption and the formation of viscoelastic film (Wilde 2000a). Heating protein at temperature above $60^{\circ} \mathrm{C}$ can increase the hydrophobicity and surface activity, thus enhance protein adsorption ability and decrease the surface tension which contributes to better foamability (Raikos and others 2007). However, Davis and Foegeding (2004) reported that the air phase fraction (which relates to overrun) of native WPI was higher than that of heated WPI. Note that they prepared the solutions at $10 \%$ protein where native WPI could already form measurable foam; thus, heated aggregates formed could be larger than in our study (5\% protein) which resulted in negative effects on the protein adsorption rate to the interface. Similar to the WPI- $\lambda \mathrm{C}$ 
system, addition of $0.05 \% \lambda \mathrm{C}$ resulted in a significant increase in overrun of both $\mathrm{pWPI}-\lambda \mathrm{C}$ and h-cpx systems with a slight higher overrun for pWPI- $\lambda \mathrm{C}$. The overrun did not change when $\lambda \mathrm{C}$ was increased to $0.15 \%$ but significantly decreased at $0.25 \%$. Interestingly, foaming ability of both pWPI- $\lambda \mathrm{C}$ and $\mathrm{h}-\mathrm{cpx}$ was significantly higher than that of WPI- $\lambda \mathrm{C}$ across all $\lambda \mathrm{C}$ concentrations. In comparison with $\mathrm{pWPI}-\lambda \mathrm{C}$ systems, heated soluble complex showed slightly lower overrun at 0.05 and $0.15 \%$ but no difference was found at $0.25 \% \lambda \mathrm{C}$. Comparing the effect of $\mathrm{k}$-carrageenan on foamability of native and denatured soy protein, Carp and others (2004) reported better foamability from heated soy protein with added $\mathrm{k}$-carrageenan than the native system. In another study, Mott and others (1999) compared the foaming properties of heated and unheated WPI-xanthan mixed systems and found improved foamability in heated systems. It was proposed that improved foamability of heated WPI-xanthan was a result of protein denaturation leading to increase protein-protein interaction. Overall, our results clearly indicated that mixed WPI- $\lambda \mathrm{C}$ in heated systems (both pWPI- $\lambda \mathrm{C}$ and h-cpx) had much improved overrun than the unheated mixed systems. Not much difference was found between pWPI- $\lambda \mathrm{C}$ and $h-c p x$ across all $\lambda C$ concentrations. Unfolding and protein-protein interaction during heating as well as interaction between WPI and $\lambda \mathrm{C}$ (even at $\mathrm{pH}>\mathrm{pl}$ ) played a large role in foamability. Studies have suggested that the interaction between protein and polysaccharide at $\mathrm{pH}>\mathrm{pl}$ improves the amount of adsorbed protein at the interface (Dickinson 2003; Baeza and others 2005).

Foam stability 
Foam stability was assessed by measuring drainage $1 / 5$ life, which equals to the time required for $1 / 5$ of the liquid to drain from foam. Results shown in Fig. $3 b$ reveal that foam stability increased with increasing polysaccharide concentrations across all WPI- $\lambda$ C systems. Similar findings on the effect of polysaccharide concentration on foam stability of protein have been reported (Mott and others 1999; Carp and others 2004; Schmitt and others 2005; Perez and others 2009a). Both pWPI- $\lambda \mathrm{C}$ and $\mathrm{h}-\mathrm{cpx}$ foams were significantly more stable than unheated WPI- $\lambda$ C at all $\lambda C$ concentrations. Both polysaccharide and heat treatment could result in increased aqueous phase viscosity which was one of the major factors in enhancing foam stability (ErÇElebi and IbanoĞLu 2009; Davis and Foegeding 2004; Hailing and Walstra 1981). Higher viscosity limits the mobility of aqueous phase surrounded air bubbles, thus improves the ability of foam to resist drainage. Higher water binding capacity of denatured proteins than the native protein could result in the chemically and physically trapped liquid in the protein network, which also limits the movement of aqueous phase and increases foam stability (Bals and Kulozik 2003a). Besides, protein and polysaccharide interaction could play an important role in the properties of adsorbed film at the interface. Perez and others (2009a) indicated that an increase in the surface dilatational modulus at long adsorption time in the WPCSA and WPI- $\lambda C$ systems explained the enhancement of foam stability. Complexation of soy protein isolate and $\lambda \mathrm{C}$ at $\mathrm{pH} 7.0$ also led to increased surface pressure and interfacial dilatational elasticity (Martinez et al., 2007). Compared with $\mathrm{pWPI}-\lambda \mathrm{C}, \mathrm{h}-\mathrm{cpx}$ foams were significantly more stable at 0.15 and 
$0.25 \% \lambda \mathrm{C}$, suggesting that, after certain minimum $\lambda \mathrm{C}$ concentration, formation of heated soluble complex could greatly enhance foam stability. It is possible that a stronger interaction that occur during heating the biopolymers contribute to stronger protein film, which hinders foam destabilization process. 

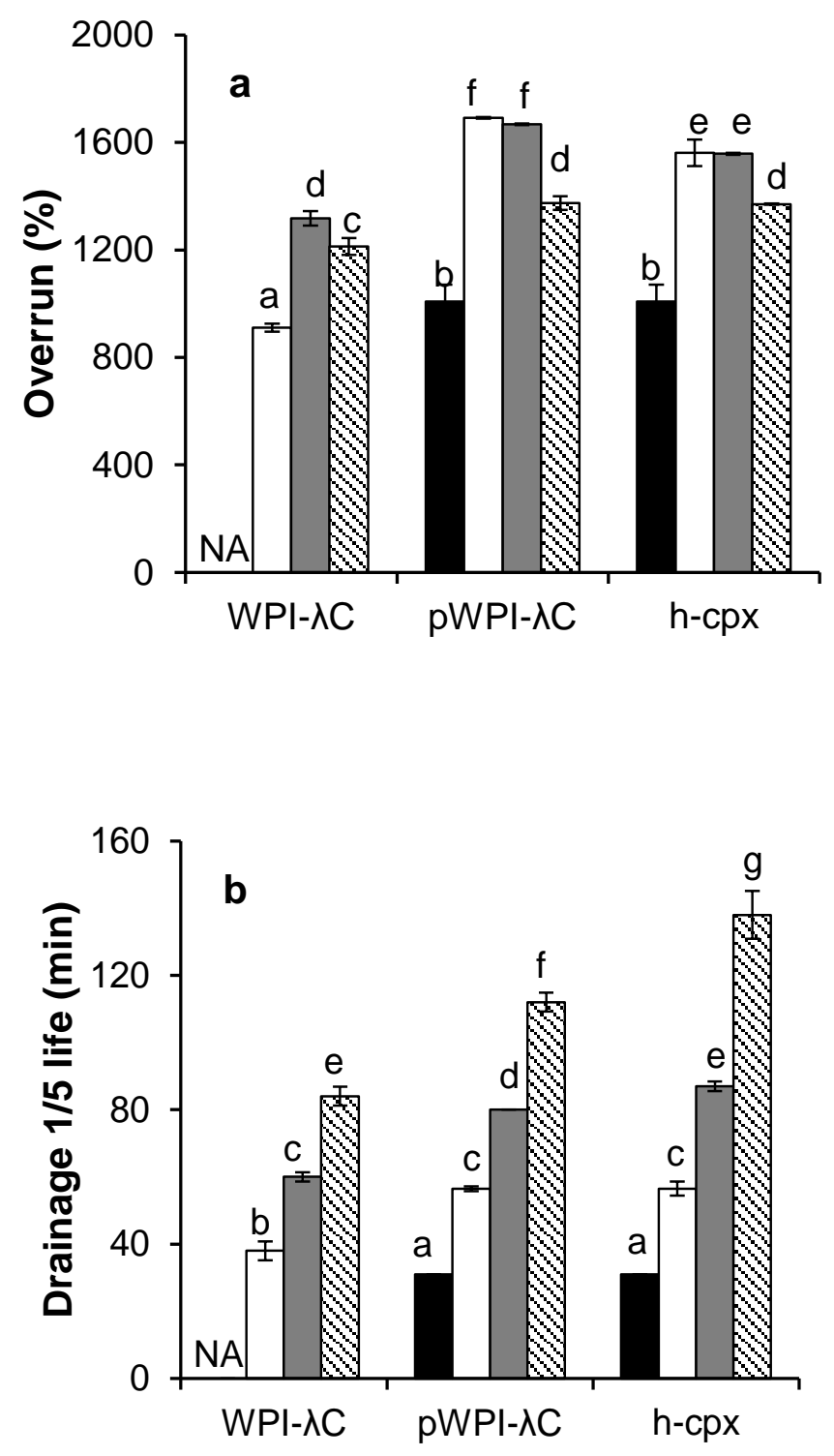

Figure 3. Overrun (a) and drainage $1 / 5$ life (b) of WPI and $\lambda C$ mixed systems with $0 \%$ (black), $0.05 \%$ (white), $0.15 \%$ (gray) and $0.25 \% \lambda \mathrm{C}$ (diagonal stripes) at $\mathrm{pH} 7$. The pWPI- $\lambda \mathrm{C}$ and $\mathrm{h}$-cpx systems were heated for $15 \mathrm{~min}$ under $85^{\circ} \mathrm{C}$. 


\subsection{Effect of $\mathrm{pH}$ of pre-foam solution on foaming properties}

Our results above suggest that formation of heated soluble complex at $\mathrm{pH} 7$ may be beneficial especially in improving foam stability. Interactions between proteins or protein and polysaccharide also depend on $\mathrm{pH}$ (Dickinson 2008). Electrostatic interactions between the positively charged patches on the proteins and negatively charged polysaccharide at $\mathrm{pH}>\mathrm{pl}$ could increase when $\mathrm{pH}$ is lowered. Thus, in order to prove that electrostatic interaction plays an important role, the effect of $\mathrm{pH}$ was also investigated. Fig. 4a shows the effect of $\mathrm{pH}$ on the overrun of three protein and $\lambda \mathrm{C}$ mixed systems. Lowering the $\mathrm{pH}$ from 7.0 to 6.2 led to a slight increase in overrun of unheated WPI- $\lambda$ C from $1213 \%$ to $1323 \%$. No difference in overrun between $\mathrm{pH} 7.0$ and 6.5 for $\mathrm{pWPI}-\lambda \mathrm{C}$ overrun, while a slight decreased overrun was observed for h-cpx. When the $\mathrm{pH}$ was reduced to 6.2 the overrun of both $\mathrm{pWPI}-\lambda \mathrm{C}$ and $\mathrm{h}-\mathrm{cpx}$ significantly decreased. Studies on the effect of $\mathrm{pH}$ on foaming properties of milk and whey proteins have shown opposite results compared to the WPI- $\lambda \mathrm{C}$ systems. Foamability of skimmed milk decreased with decreasing $\mathrm{pH}$ in the range of 7.0 to 6.4 (Borcherding and others 2009). Zhang and others (2004) also reported decreased foamability of WPI and skim milk powder when $\mathrm{pH}$ was decreased from 7.0 to 6.0. One factor that affects foaming ability is the viscosity of the pre-foam solutions. Increased viscosity can lead to reduced foamability due to slower diffusion rate of the protein to the interface. We found that the viscosity (at $125 \mathrm{~s}^{-1}$ ) of WPI- $\lambda \mathrm{C}$ at $\mathrm{pH}$ 6.2 was higher than that at $\mathrm{pH} 7.0$ (24.1 and $3.7 \mathrm{mPa}$ s, respectively, Table 2), thus higher overrun at $\mathrm{pH} 6.2$ was not due to the viscosity but was more likely 
due to higher degree of interaction between WPI and $\lambda C$. For heated samples, the pre-foam solutions at $\mathrm{pH} 6.2$ became very turbid, indicating an increase in particle size. Particle size is one of the major factors affecting the adsorption of protein at the interface. Larger particles diffuse to the interface at a slower rate, resulting in lowered foamability. Larger particles size may be the reason for decreased overrun of heated systems at $\mathrm{pH}$ 6.2.

The effects of $\mathrm{pH}$ on drainage $1 / 5$ life are shown in Fig. 4b. Decreasing the $\mathrm{pH}$ from 7.0 to 6.2 resulted in increased foam stability of all WPI- $\lambda \mathrm{C}$ systems. Improved foam stability at lower $\mathrm{pH}$ could be due to the decrease in charge repulsion which led to the formation of stronger interfacial film (Zhang and others 2004). In addition, increased viscosity was found to influence foam stability. Compared to samples at $\mathrm{pH} 7.0, \mathrm{WPI}-\lambda \mathrm{C}$ and $\mathrm{pWPI}-\lambda \mathrm{C}$ at $\mathrm{pH} 6.2$ had higher viscosity; however, that was not the case for $\mathrm{h}-\mathrm{cpx}$ where $\mathrm{pH} 6.2$ samples had lowered viscosity. Across all $\mathrm{pH}$ values, drainage $1 / 5$ life of both heated systems was higher than WPI- $\lambda C$, and h-cpx showed higher drainage $1 / 5$ life than pWPI$\lambda C$. Intriguingly, h-cpx foams at $\mathrm{pH} 6.2$ were much more stable than $\mathrm{pWPI}-\lambda \mathrm{C}$. This further confirms the conclusion that the formation of soluble complex leads to superior foam stability. At pH 6.2, the electrostatic repulsion between the protein and $\lambda C$ was reduced and electrostatic interactions (between positive patches on the protein and $\lambda C$ ) as well as hydrophobic interaction were enhanced, leading to the formation of stronger interfacial film and more stable foams. This result supports our speculation that the interactions, including 
electrostatic interaction, between WPI and $\lambda \mathrm{C}$ during heating were largely responsible for their improved foam stability. 

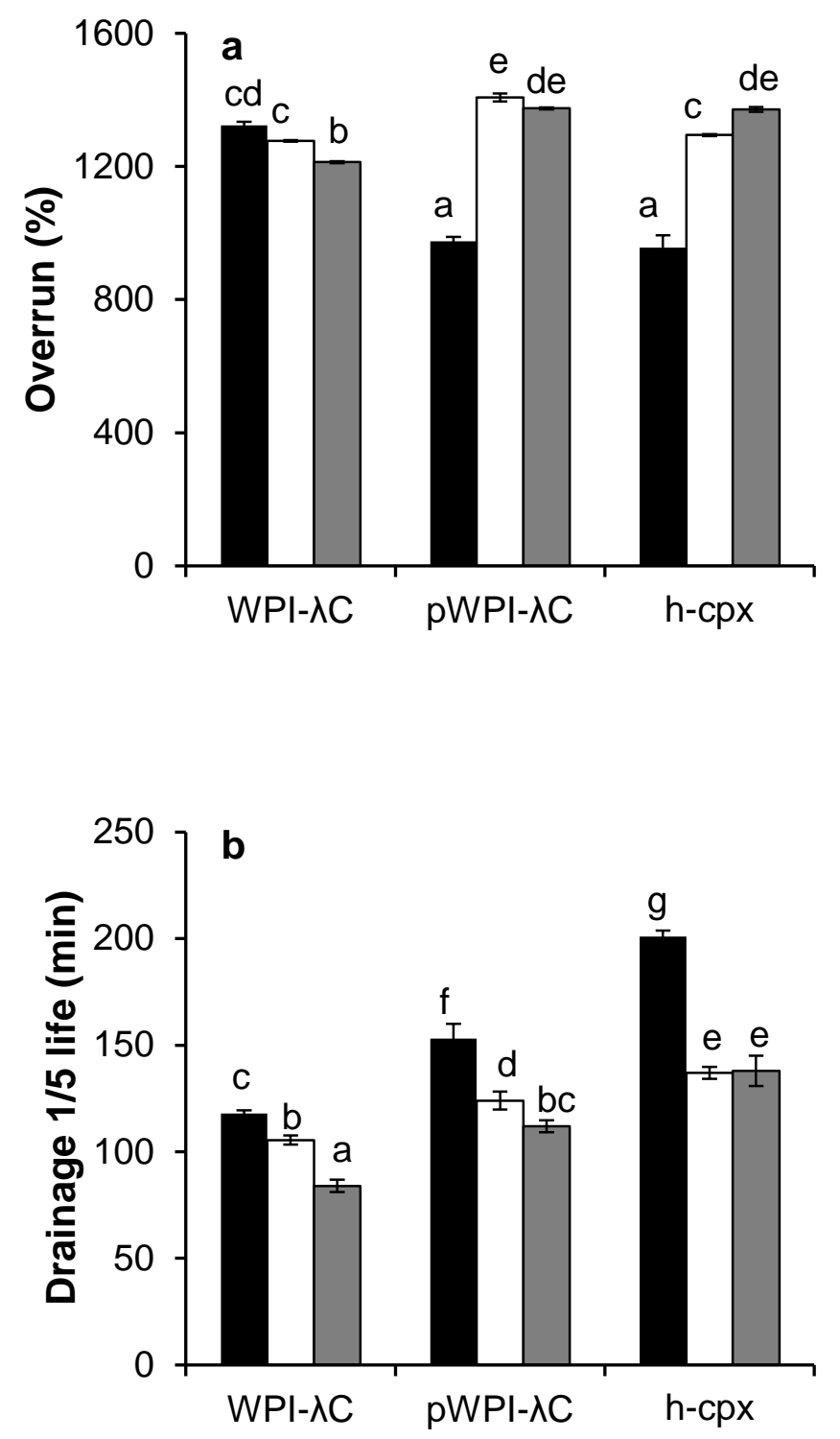

Figure 4. Overrun (a) and drainage 1/5 life (b) of WPI and $\lambda \mathrm{C}$ mixed systems (with $0.25 \% \lambda \mathrm{C}$ ) under $\mathrm{pH} 6.2$ (black), $\mathrm{pH} 6.5$ (white) and $\mathrm{pH} 7.0$ (gray). Systems of pWPI- $\lambda \mathrm{C}$ and $\mathrm{h}$-cpx were heated for 15 min under $85^{\circ} \mathrm{C}$. 
Table 2. Viscosity of WPI- $\lambda \mathrm{C}$ mixed systems with different $\lambda \mathrm{C}$ concentration and different $\mathrm{pH}$. Systems of pWPI- $\lambda \mathrm{C}$ and $\mathrm{h}-\mathrm{cpx}$ were heated for 15 min under $85^{\circ} \mathrm{C}$.

\begin{tabular}{|c|c|c|c|c|}
\hline \multirow{2}{*}{ System } & \multirow{2}{*}{$\mathrm{pH}$} & \multirow{2}{*}{$\begin{array}{c}\lambda C \text { concentration } \\
(\%)\end{array}$} & \multicolumn{2}{|c|}{ Viscosity (mPas) } \\
\hline & & & $8 \mathrm{~s}^{-1}$ & $125 \mathrm{~s}^{-1}$ \\
\hline \multirow[t]{4}{*}{ WPI- $\lambda C$} & 7.0 & 0.05 & $11.7 \pm 1.8^{\mathrm{a}}$ & $3.74 \pm 0.11^{\mathrm{a}}$ \\
\hline & & 0.15 & $21.2 \pm 5.3^{a}$ & $9.05 \pm 0.21^{b}$ \\
\hline & & 0.25 & $40.5 \pm 9.1^{b}$ & $19.6 \pm 0.1^{d}$ \\
\hline & 6.2 & 0.25 & $56.8 \pm 3.1^{c}$ & $24.1 \pm 0.8^{\dagger}$ \\
\hline \multirow[t]{4}{*}{ pWPI- $\lambda C$} & 7.0 & 0.05 & $67.7 \pm 8.4^{\mathrm{cd}}$ & $9.55 \pm 0.13^{b}$ \\
\hline & & 0.15 & $87.4 \pm 11.7^{\text {ef }}$ & $18.5 \pm 0.9^{\mathrm{cd}}$ \\
\hline & & 0.25 & $109 \pm 6^{g}$ & $25.3 \pm 0.6^{\operatorname{tg}}$ \\
\hline & 6.2 & 0.25 & $125 \pm 7^{\mathrm{h}}$ & $36.1 \pm 0.2^{i}$ \\
\hline \multirow[t]{4}{*}{ h-cpx } & 7.0 & 0.05 & $76.0 \pm 5.2^{\mathrm{de}}$ & $9.70 \pm 0.17^{b}$ \\
\hline & & 0.15 & $93.5 \pm 4.6^{\dagger}$ & $17.5 \pm 2.4^{c}$ \\
\hline & & 0.25 & $108 \pm 9^{9}$ & $26.3 \pm 0.7^{9}$ \\
\hline & 6.2 & 0.25 & $73.1 \pm 0.3^{\mathrm{de}}$ & $29.1 \pm 0.0^{h}$ \\
\hline
\end{tabular}




\subsection{Zeta-potential and particle size of heated solution}

Particle size and zeta-potential measurements were used to characterize $\mathrm{pWPI}-\lambda \mathrm{C}$ and $\mathrm{h}-\mathrm{cpx}$ in order to determine whether or how molecular properties were related to foaming properties. The Z-average mean diameters of each system at different $\lambda \mathrm{C}$ concentrations and $\mathrm{pH}$ are shown in Table 3. Particle size distributions of native WPI alone and $\lambda \mathrm{C}$ alone showed one single peak at around $9 \mathrm{~nm}$ and $1,000 \mathrm{~nm}$, respectively (data not shown). In native WPI- $\lambda \mathrm{C}$ mixed systems, two peaks were exhibited in the size distribution. For example, in native WPI added with $0.25 \% \lambda C$, particle size distribution showed one peak at $44.4 \mathrm{~nm}$ and another at $1057.3 \mathrm{~nm}$, while the native WPI peak $(9.90 \pm 0.51 \mathrm{~nm})$ disappeared. This suggests that some interactions between protein and polysaccharide existed in native WPI- $\lambda$ C system. Vardhanabhuti and others (2009) also reported the formation of higher molecular weight complex as shown by size exclusion chromatography coupled with multi angle laser light scattering in mixed native $\beta$-lg and dextran sulfate at near neutral $\mathrm{pH}$.

Particle size distribution of h-cpx samples showed one single peak, suggesting the formation of a complex. Similar results had been reported for heating pectin and protein at $\mathrm{pH}>\mathrm{pl}$ (Zhang and others 2013). For pWPI- $\lambda \mathrm{C}$ samples, a single peak was also observed which was in agreement with other studies that reported the interactions between protein polymer and anionic polysaccharide under net negative conditions (De Jong and others 2009). Compared to $\mathrm{pWPI}-\lambda \mathrm{C}$ at the same $\lambda \mathrm{C}$ concentration, $\mathrm{h}-\mathrm{cpx}$ formed larger particles at $\mathrm{pH} 7$ at all $\lambda \mathrm{C}$ concentrations. Decreasing $\mathrm{pH}$ to 6.5 resulted in 
significantly larger particles for h-cpx and the h-cpx particles was larger than pWPI- $\lambda \mathrm{C}$. Opposite results were found at $\mathrm{pH} 6.2$ where $\mathrm{h}-\mathrm{cpx}$ showed smaller size than $\mathrm{pWPI}-\lambda \mathrm{C}$ although increased compared to $\mathrm{pH} 6.5$ or $\mathrm{pH}$ 7.0. The effect of $\mathrm{pH}$ on particle size of heated WPI-pectin soluble complex was reported by Zhang and others (2013). As previously discussed, the lowered foamability is likely contributed to the large particle size at lower $\mathrm{pH}$. Davis and Foegeding (2004) indicated that larger particle size of heated WPI led to lowered diffusion rate of protein to the interface compared with native WPI, resulting in decreased foamability. The protein aggregates adsorbed at the interface could contribute to the more elastic films which enhanced foam stability. Bals and Kulozik (2003a) reported that large extent of WPI aggregation significantly lowered the overrun.

In colloidal systems, zeta-potential is known as electro-kinetic potential, which reveals the difference between the dispersion medium and the stationary layer of fluid attached to the dispersed particle (Hunter 1981). The significance of measuring zeta potential is its relation to the stability of colloidal dispersions. Table 3 shows the effect of $\lambda \mathrm{C}$ concentration and $\mathrm{pH}$ on zeta-potential of prefoam solutions. The zeta-potential of native WPI solution was $-25 \pm 0.6 \mathrm{mV}$ (data not shown). Heating led to unfolding of protein, thus more charged regions were exposed, resulting in more negative zeta-potential. Addition of negatively charged $\lambda C$ greatly affected the surface charge density of the proteins. Both $\mathrm{pWPI}-\lambda \mathrm{C}$ and $\mathrm{h}-\mathrm{cpx}$ systems showed increasing negative charge with increasing $\lambda \mathrm{C}$ concentration and $\mathrm{pH}$. At $\mathrm{pH} 7$ and $6.5, \mathrm{~h}-\mathrm{cpx}$ with $0.25 \% \lambda \mathrm{C}$ were significantly more negatively charged than pWPI- $\lambda \mathrm{C}$. With increasing $\lambda \mathrm{C}$ 
concentration, foam stability increased which was probably associated with the increased negative charge. Hanaor and others (2012) indicated that the particles with higher absolute zeta potential are more stable due to the stronger repulsion between particles. Damodaran (2005) also stated that the repulsion forces blocked the bubbles' approach to each other, thus further enhanced the foam stability. However, much more stable foams were produced at $\mathrm{pH} 6.2$ where the system processed lower zeta-potential, suggesting that other factors also contributed to higher foam stability. This supports the speculation that stronger interactions occurred during heating, the complex lead to stronger film and increased foam stability. 
Table 3. Particle size and zeta-potential of $\mathrm{h}-\mathrm{cpx}$ and $\mathrm{pWPI}-\lambda \mathrm{C}$ systems heated for 15 min under $85^{\circ} \mathrm{C}$ with different $\lambda \mathrm{C}$ concentrations and under different $\mathrm{pH}$.

\begin{tabular}{ccccc}
\hline System & $\mathrm{pH}$ & $\begin{array}{c}\lambda \mathrm{C} \text { concentration } \\
(\%)\end{array}$ & $\begin{array}{c}\text { Particle size } \\
(\mathrm{Z} \text {-average, } \mathrm{nm})\end{array}$ & $\begin{array}{c}\text { Zeta Potential } \\
(\mathrm{mV})\end{array}$ \\
\hline pWPI- $\lambda \mathrm{C}$ & 7.0 & 0.00 & $40.4 \pm 0.1^{\mathrm{a}}$ & $-28.1 \pm 0.8^{\mathrm{g}}$ \\
& & 0.05 & $44.2 \pm 0.8^{\mathrm{b}}$ & $-32.5 \pm 0.5^{\mathrm{f}}$ \\
& & 0.15 & $46.6 \pm 0.3^{\mathrm{c}}$ & $-38.8 \pm 0.4^{\mathrm{e}}$ \\
& & 0.25 & $56.7 \pm 0.6^{\mathrm{g}}$ & $-47.4 \pm 1.1^{\mathrm{b}}$ \\
& 6.5 & 0.25 & $54.9 \pm 0.2^{\mathrm{j}}$ & $-44.4 \pm 0.3^{\mathrm{d}}$ \\
$\mathrm{h}-\mathrm{cpx}$ & 6.2 & 0.25 & $101 \pm 1^{\mathrm{k}}$ & $-44.8 \pm 1.0^{\mathrm{cd}}$ \\
& 7.0 & 0.00 & - & - \\
& & 0.05 & $51.7 \pm 0.5^{\mathrm{d}}$ & $-31.7 \pm 0.8^{\mathrm{f}}$ \\
& & 0.15 & $53.1 \pm 0.4^{\mathrm{e}}$ & $-38.4 \pm 1.2^{\mathrm{e}}$ \\
& & 0.25 & $60.6 \pm 0.4^{\mathrm{h}}$ & $-50.5 \pm 0.8^{\mathrm{a}}$ \\
& 6.5 & 0.25 & $63.2 \pm 0.6^{\mathrm{i}}$ & $-47.0 \pm 0.2^{\mathrm{b}}$ \\
& 6.2 & 0.25 & $90.2 \pm 0.4^{\mathrm{j}}$ & $-45.5 \pm 0.8^{\mathrm{c}}$ \\
\hline
\end{tabular}




\subsection{Viscosity of pre-foam solution}

Viscosity of pre-foam solutions is one factor related to foaming properties. The viscosities at very low shear rate $\left(8 \mathrm{~s}^{-1}\right)$ and high shear rate $\left(125 \mathrm{~s}^{-1}\right)$ have been found to correlate to foam stability and overrun, respectively (Davis and Foegeding 2004; Hailing and Walstra 1981). Increasing viscosity hinders the air incorporation in the bubbles during foam formation and retards the protein diffusion to the interface. Thus, generally a negative relationship exists between the viscosity at $125 \mathrm{~s}^{-1}$ (whipping shear rate) and overrun in heated systems. However, no correlation exists when the overrun of all three systems at $\mathrm{pH} 7.0$ was plotted against the viscosity at $125 \mathrm{~s}^{-1}$ (Fig. 5a). This is mainly due to WPI$\lambda C$ samples which had increased overrun as $\lambda C$ concentration increased from $0.05 \%$ to $0.25 \%$. When plotting only $\mathrm{pWPI}-\lambda \mathrm{C}$ and $\mathrm{h}$-cpx samples, a negative linear relationship between overrun and viscosity could be established as followed:

$y=-15373 x+1771.3$, where $y=$ overrun and $x=$ viscosity, $R^{2}=0.9838$

A positive linear relationship $\left(R^{2}=0.7698\right)$ exists between foam stability and pre-foam solution viscosity as shown in Fig. $5 b$. Increased viscosity of continuous phase has been found to slow down the drainage rate and improve foam stability (Davis and Foegeding 2004; Mishra and others 2001; Silva and others 2008; Seguineau De Preval and others 2013; Bals and Kulozik 2003b). In addition, interesting results were revealed when drainage 1/5 life and viscosity relationship in each system was determined separately (Fig. 5c). The slope value of h-cpx system was the largest (3.16) followed by pWPI- $\lambda \mathrm{C}$ (1.92) and the smallest slope 
(1.43). This further supports that $\mathrm{h}-\mathrm{cpx}$ had the most stable foam, and other factors contributed to foam stability in addition to viscosity.

The major difference among the three systems is the degree of proteinprotein and protein- polysaccharide interactions. For WPI- $\lambda \mathrm{C}$, with protein being folded and the net negative charged condition, there are very limited interactions among proteins and protein and $\lambda \mathrm{C}$. In $\mathrm{pWPI}-\lambda \mathrm{C}$ system, the interactions between proteins are promoted during the formation of protein polymer when heating protein alone. Addition of $\lambda \mathrm{C}$ leads to some interactions between protein polymer and $\lambda \mathrm{C}$. However, for $\mathrm{h}-\mathrm{cpx}$, whey protein is unfolded during heating and at the same time, interactions between protein and $\lambda C$ via electrostatic interactions, hydrophobic interactions, and others are promoted. Therefore the interactions in heated soluble complex could play an important role at the interface that contributed to foam stabilization. 

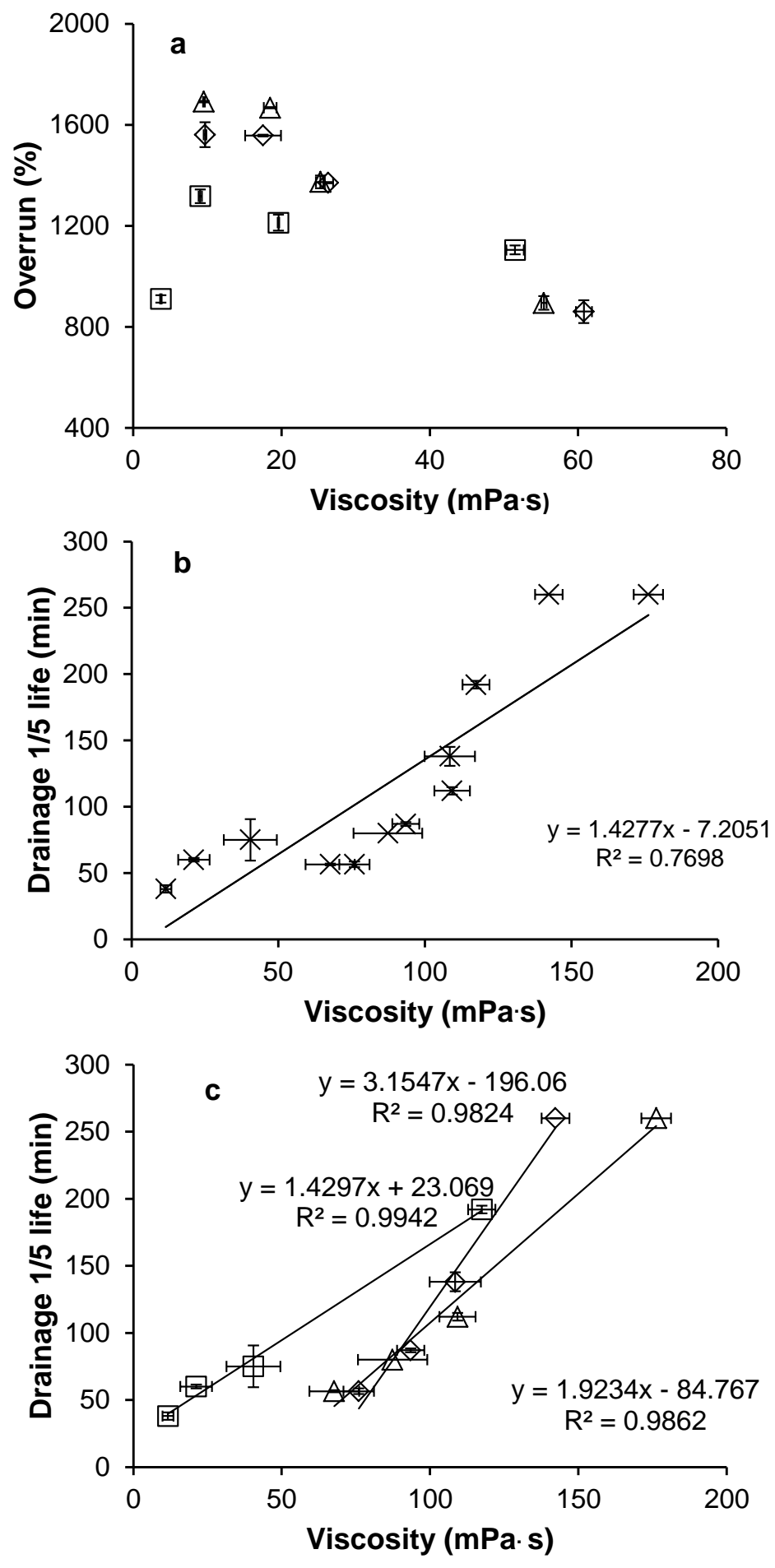

Figure 5. Relations between foam properties and pre-foamed solution viscosity at $\mathrm{pH}$ 7. Systems of pWPI- $\lambda \mathrm{C}$ and h-cpx were heated for 15 min under $85^{\circ} \mathrm{C}$. $(\mathrm{a}, \mathrm{c})$ Foam properties VS. Viscosity of three WPI- $\lambda$ C mixed systems. WPI- $\lambda$ C ( $\square$ ) pWPI- $\lambda C(\Delta)$ h-cpx $(\diamond)($ b) Foam stability VS. Viscosity. All systems shown as $(\mathrm{x})$. 


\subsection{Rheological behavior of foams}

Viscoelastic properties of foam during destabilization were studied using dynamic oscillatory experiments. Amplitude sweep was conducted immediately after foam formation. From the results shown in Fig.6, the linear viscoelastic region (LVR) of foams from all three treatments was between strain values of 0.01 to 0.1 . Foams behave like elastic solids within LVR but respond like liquid beyond that region (Jimenez-Junca and others 2011; Höhler and Cohen-Addad 2005). Since the foam structure changes continuously due to destabilization, one can expect changes of viscoelastic properties to occur even during the course of a rheological experiment. However, the measured data on the storage modulus ( $G^{\prime}$, elastic rigidity) and loss modulus ( $G^{\prime \prime}$, viscous rigidity) were quite stable and reproducible. $G^{\prime}$ and $G^{\prime \prime}$ of both heated systems were higher than those of WPI$\lambda C$, supporting previous results that heated systems were more stable than unheated system. Similar responses were observed for $\mathrm{pWPI}-\lambda \mathrm{C}$ and $\mathrm{h}-\mathrm{cpx}$. Frequency sweep experiments were carried out within the LVR (at $0.05 \%$ strain) which allowed the determination under conditions that approach the steady state. Fig. 7 shows the changes of $G^{\prime}$ and $G^{\prime \prime}$ for the three systems containing $0.25 \%$ $\lambda C$. The elastic modulus was $3.12,3.9$ and 4.1 times higher than the viscous modulus in WPI- $\lambda \mathrm{C}, \mathrm{pWPI}-\lambda \mathrm{C}$ and $\mathrm{h}-\mathrm{cpx}$ systems, respectively, indicating a high elastic nature of these foams, especially in $\mathrm{h}-\mathrm{cpx}$ foams. Elastic modulus and viscous modulus of $h-c p x$ and $p W P I-\lambda C$ were higher than WPI- $\lambda C$. The molecular interactions in heated samples resulted in the formation of thicker and more elastic films. Allen and others (2008) reported that additional protein and low- 
methoxyl pectin interactions increased the elastic modulus and yield strain of the foam. In our study, h-cpx with $0.25 \% \lambda C$ produced more stable foams compared to $\mathrm{pWPI}-\lambda \mathrm{C}$. However, both $\mathrm{h}-\mathrm{cpx}$ and $\mathrm{pWPI}-\lambda \mathrm{C}$ showed very similar trends in the changes of moduli from both amplitude sweep and frequency sweep. 

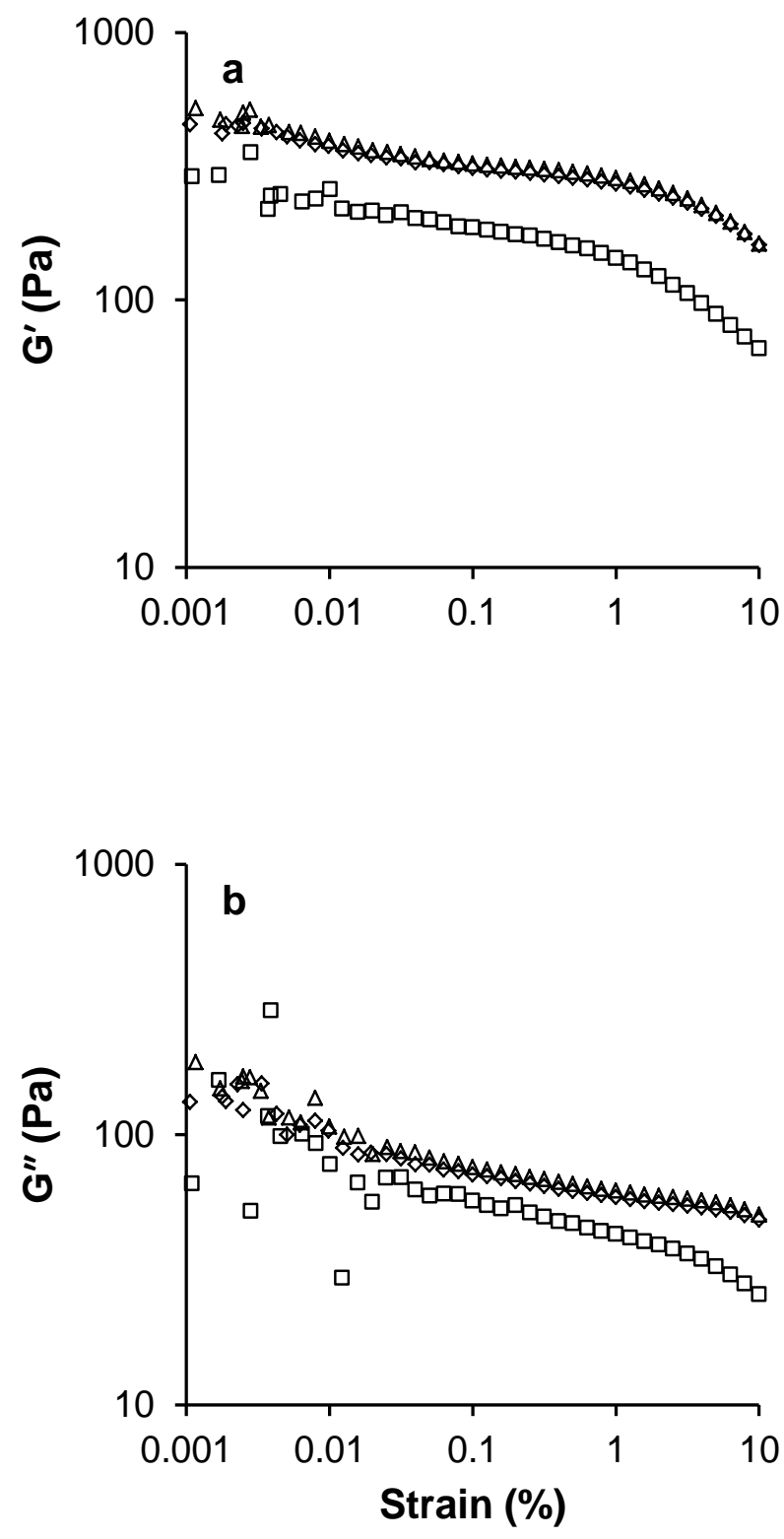

Figure 6. Amplitude sweep plot for WPI- $\lambda C(\square)$ pWPI- $\lambda C(\Delta)$ h-cpx $(\diamond)$ with $0.25 \%$ $\lambda \mathrm{C}$ at $\mathrm{pH}$ 7. (a)Elastic modules at $0.5 \mathrm{~Hz}$ frequency (b) Viscous modules at 0.5 $\mathrm{Hz}$ frequency. 

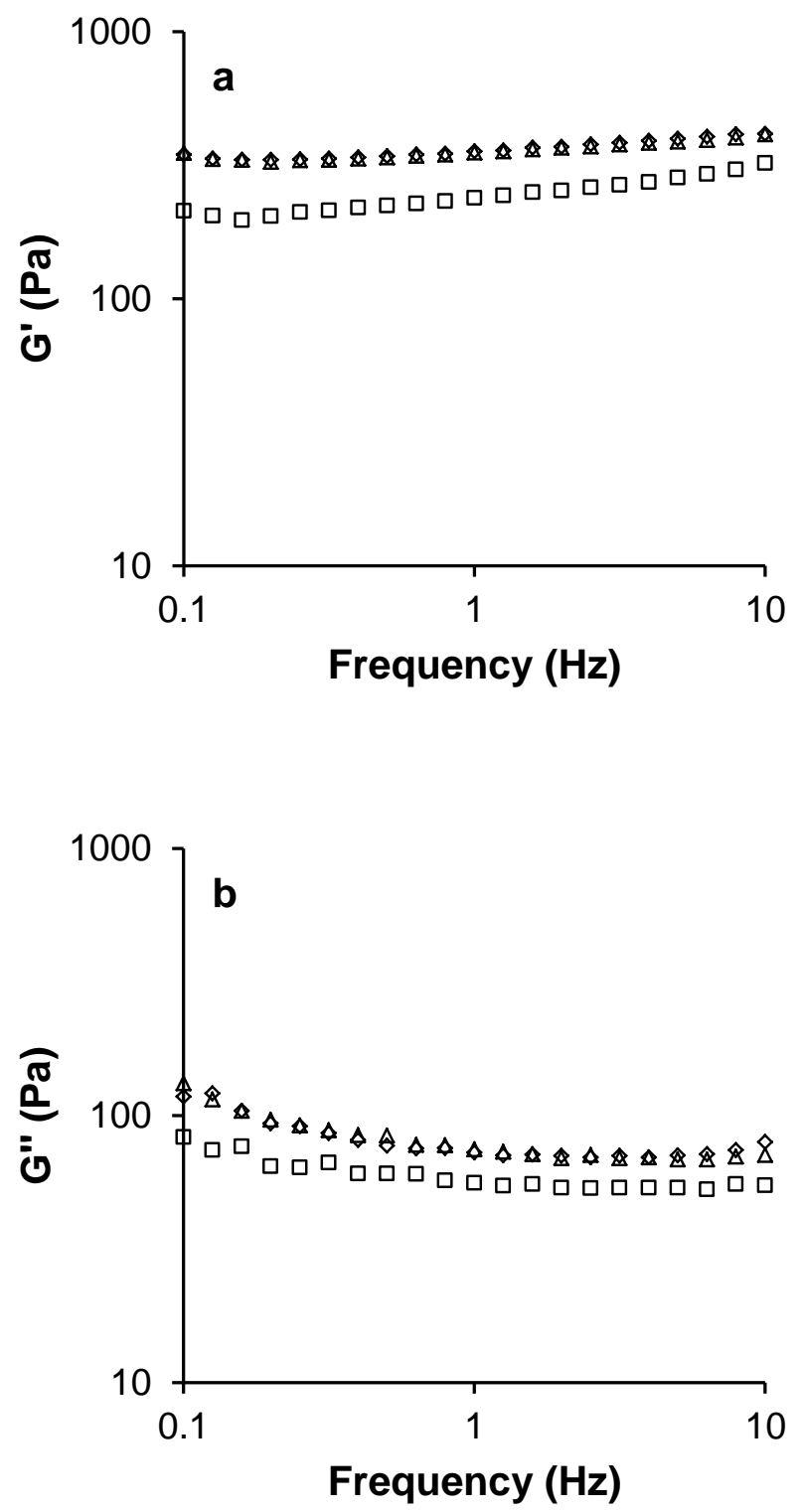

Figure 7. Frequency sweep plot for WPI- $\lambda C(\square)$ pWPI- $\lambda C(\Delta)$ h-cpx $(\diamond)$ with $0.25 \%$ $\lambda \mathrm{C}$ at $\mathrm{pH}$ 7. (a)Elastic modules at fixed $0.05 \%$ strain (b) Viscous modules at fixed $0.05 \%$ strain. 


\subsection{Microstructure analysis of foams}

Confocal laser scanning microscopy (CLSM) combined with image analysis was used to characterize foam microstructure and bubble size distribution of foams. The time lapse images of three WPI and $\lambda \mathrm{C}$ mixed systems were taken at $10,13,16,19$ and 22 min after foam generation in three replications and the representative images are shown in Fig. 8. The aqueous protein solution is shown as the lighter gray phase while the bubbles are black. Time lapse images at 10 min revealed that all foams contained both small and large bubbles. The large bubbles grew very large over time at the expense of smaller bubbles. Foams from h-cpx and pWPI- $\lambda \mathrm{C}$ also showed thicker film and Plateau border (labeled A in Fig. 8) surrounding the air bubbles which had positive effects on blocking diffusion between bubbles and hence contributed to higher foam stability. Smaller changes of the bubble structures were observed in foams from heated systems than WPI- $\lambda$ C foams which corresponded to foam stability results.

These series images revealed the movements of dispersed bubbles. Other than gravitation, Laplace pressure is another important factor related to the movement and gas diffusion of foam system and described as in following equation:

$$
\Delta P=P_{\text {inside }}-P_{\text {outside }}=\gamma\left(\frac{1}{R_{1}}+\frac{1}{R_{2}}\right)(\text { Gennes and others 2004) }
$$

Where $\mathrm{P}_{\text {inside }}$ is the pressure inside the bubble; $\mathrm{P}_{\text {outside }}$ is the pressure outside the bubble; $y$ is the surface tension and $R$ is the radius of the bubble. From this equation, higher Laplace pressure in small bubble compared to that in big bubble drives gas diffusion through continuous phase (Herzhaft 1999; Yang and 
Foegeding 2011). So the small bubbles become smaller and finally disappear and larger bubble become larger, such as the change of the bubbles marked with the triangle and cross signs, respectively (Fig. 8). The rupture of the thin liquid film of the two adjacent bubbles leads to the disappearance of some bubbles and the enlargement of the bubble area (labeled B, Fig. 8).

The image analysis was based on scanning three different positions of each treatment. The initial average bubble area of both $\mathrm{h}-\mathrm{cpx}$ and $\mathrm{pWPI}-\lambda \mathrm{C}$ foams were significantly smaller than that of WPI- $\lambda$ C foams $(p<0.05)($ Table 4$)$. When conducting pair comparison between the heated systems, the h-cpx treatment had significantly smaller bubble area than that of pWPI- $\lambda \mathrm{C}$. It had been reported that foam produced by heat-treated protein (above $80^{\circ} \mathrm{C}$ ) had smaller bubble size than foam prepared from native protein (Nicorescu and others 2009). Studies suggested that higher viscosity of continuous phase led to smaller average bubble size (Kamath and others 2008; Borcherding and others 2009). Yang and Foegeding (2011) found linear relationships between initial bubble size and foam stability for egg white protein and whey protein with sucrose. Comparing the air phase percentage at $10 \mathrm{~min}$ and $20 \mathrm{~min}$ after foaming of the three systems, the smallest change was obtained from heated soluble complex while the largest change was WPI- $\lambda \mathrm{C}$ system. The increased interactions during heating the biopolymers in h-cpx increased the elasticity of the interfacial film, reduced the mobility of aqueous phase and slowed down the rates of bubble shrinkage or growth. Based on the analysis, the smaller initial bubble size of $h-c p x$ corresponded to better foam stability, which was in agreement with other studies 
(Borcherding and others 2008). Natural logarithm values of bubble areas instead of bubble radius were used to describe the bubble size distribution. Fig. 9 shows that, foams produced from $\mathrm{pWPI}-\lambda \mathrm{C}$ and $\mathrm{h}-\mathrm{cpx}$ had more uniform bubble size compared to WPI- $\lambda$ C foams. Nicorescu and others (2009) reported that foam prepared from heated protein sample (above $80^{\circ} \mathrm{C}$ ) exhibited a narrower bubble size distribution than the native protein foam. Compared to $\mathrm{pWPI}-\lambda \mathrm{C}$, foams from heated soluble complex produced narrower bubble size distribution. Overall, results from microstructure analysis support other results that $h$-cpx foams were most stable. 


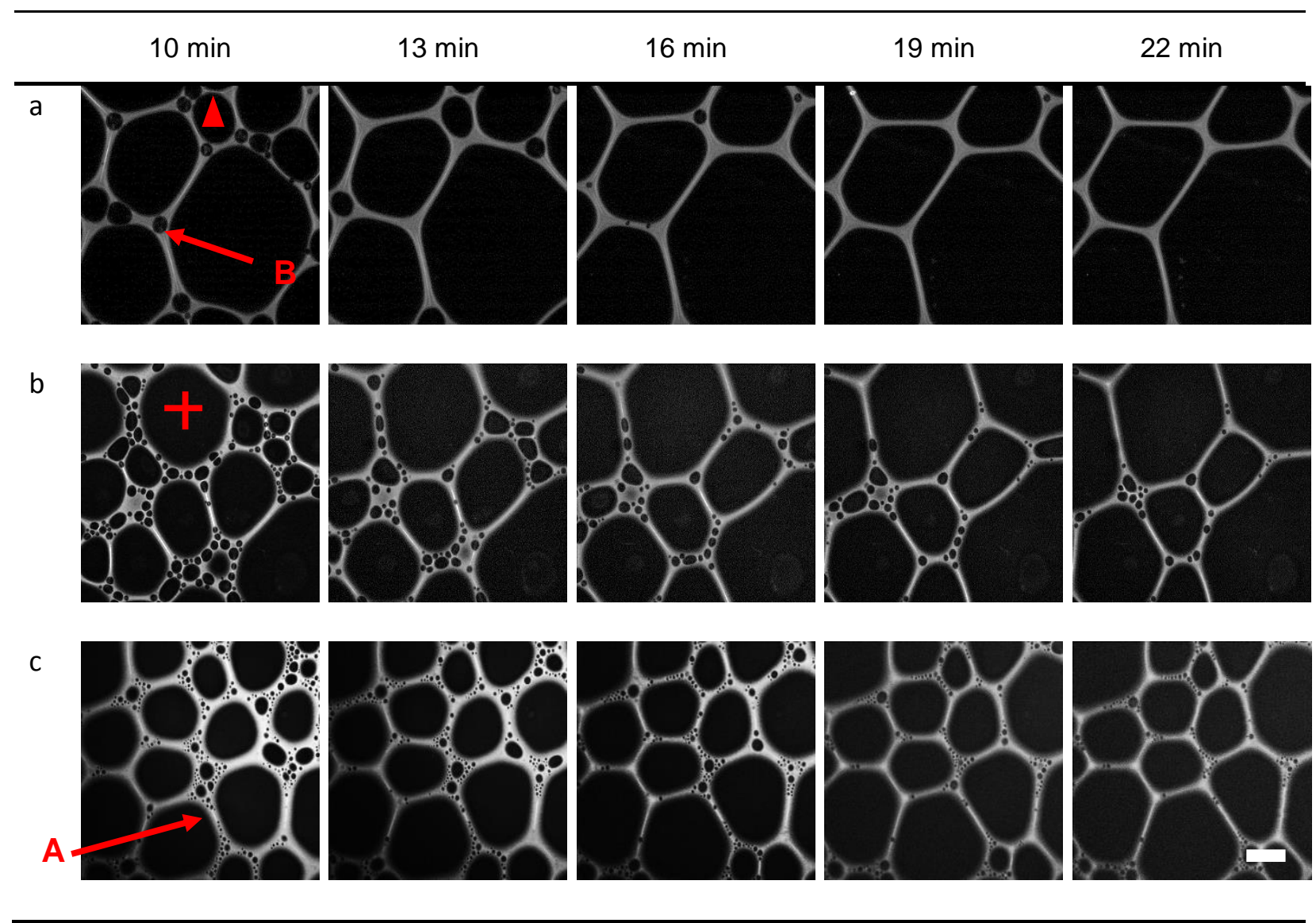

Figure 8. CLSM images of three WPI- $\lambda \mathrm{C}$ mixed systems with $0.25 \% \lambda \mathrm{C}$ at $\mathrm{pH}$ 7.0. a) WPI- $\lambda$ C system b) pWPI- $\lambda$ C system c) h-cpx system. Bar shown in the image: $200 \mu \mathrm{m}$. 
Table 4. Initial bubble area and air phase fraction of three WPI- $\lambda$ C mixed systems based on image analysis.

\begin{tabular}{cccc}
\hline & Initial average & \multicolumn{2}{c}{ Air phase percentage $\varphi_{\mathrm{g}}$} \\
\cline { 3 - 4 } Systems & bubble size $\left(\mu \mathrm{m}^{2}\right)$ & $10 \mathrm{~min}$ & $22 \mathrm{~min}$ \\
\hline WPI- $\lambda C$ & $25075 \pm 1754^{\mathrm{b}}$ & $0.822 \pm 0.055^{\mathrm{a}}$ & $0.900 \pm 0.054^{\mathrm{b}}$ \\
pWPI $\lambda \mathrm{C}$ & $4259 \pm 18^{\mathrm{aB}}$ & $0.785 \pm 0.055^{\mathrm{a}}$ & $0.835 \pm 0.016^{\mathrm{ab}}$ \\
$\mathrm{h}-\mathrm{cpx}$ & $2972 \pm 440^{\mathrm{aA}}$ & $0.780 \pm 0.021^{\mathrm{a}}$ & $0.808 \pm 0.020^{\mathrm{a}}$ \\
\hline
\end{tabular}

Different lower cases indicate the significant differences among systems.

Different upper cases indicate the significant difference between pWPI- $\lambda \mathrm{C}$ and $\mathrm{h}-\mathrm{cpx}$. 

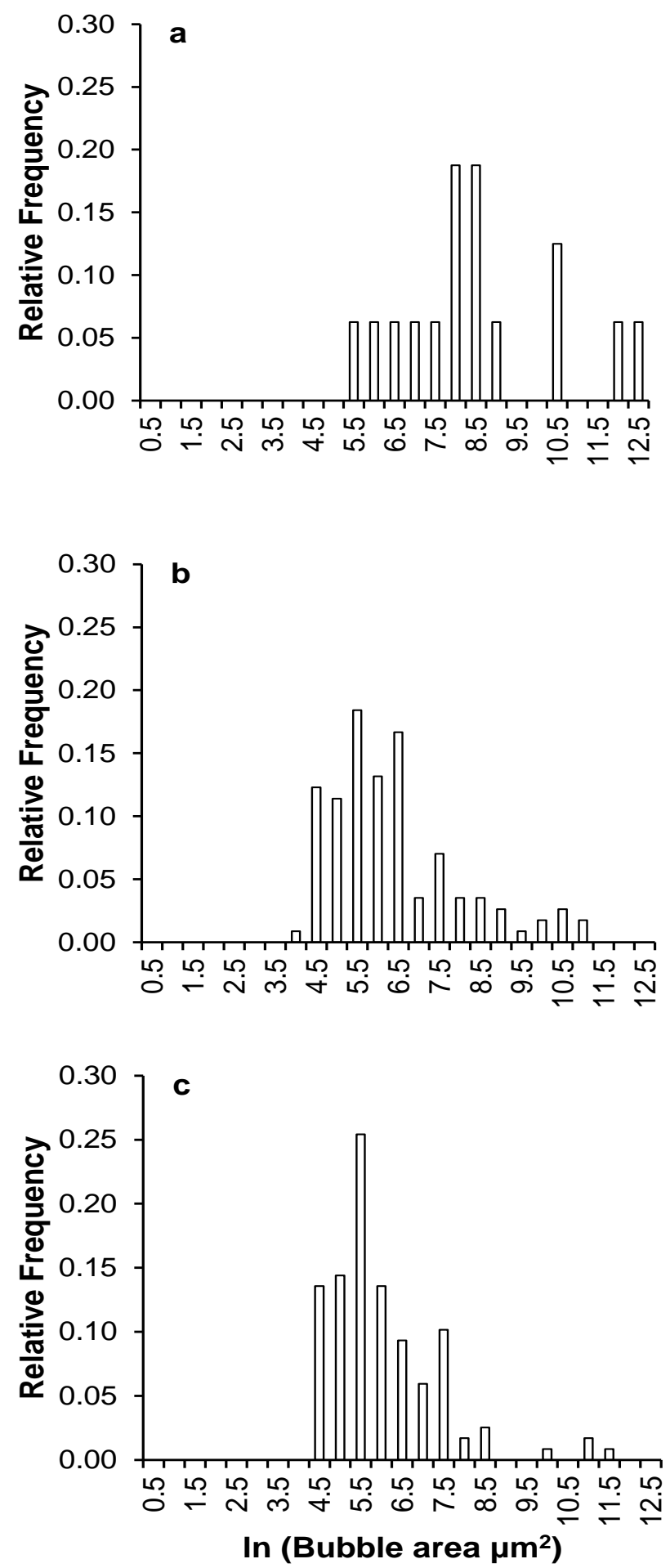

Figure 9. Histograms of bubble area in the first CLSM images (10 min) of foams made by three systems ( $\mathrm{pH} 7,0.25 \% \lambda \mathrm{C}$ and heated for 15 min under $\left.85^{\circ} \mathrm{C}\right)$. (a) WPI- $\lambda$ C system (b) pWPI- $\lambda$ C system (c) h-cpx system. 


\section{CHAPTER 6}

\section{CONCLUSION}

Based on all previous discussed data and some additional observations, some general remarks, speculations, and conclusions are made in this chapter. The goal of this thesis was to understand how anionic polysaccharides such as lambda carrageenan, influence foaming properties of whey protein when they were mixed at different conditions. The effects of heating, $\lambda \mathrm{C}$ concentration, and $\mathrm{pH}$ were investigated. To study heating effect, WPI and $\lambda \mathrm{C}$ were mixed in three different systems: unheated WPI and $\lambda C$, WPI polymer and $\lambda C$, and heated WPI and $\lambda \mathrm{C}$ soluble complex.

As expected, the presence of $\lambda \mathrm{C}$ clearly affected foaming properties of WPI.

For unheated WPI and $\lambda \mathrm{C}$ mixed system, $\lambda \mathrm{C}$ was needed in order for $5 \% \mathrm{WPI}$ to form measurable foams which was likely due to the ability of $\lambda C$ to increase viscosity of the mixture such that the foams were more stable and measurable. In all three WPI- $\lambda \mathrm{C}$ systems, increasing $\lambda \mathrm{C}$ concentration led to improved foamability which increased with increasing $\lambda C$ concentration until a certain concentration before it decreased. Increasing $\lambda C$ concentration resulted in significant increases in the drainage $1 / 5$ life. Interestingly, despite their higher viscosity, both heated systems (pWPI- $\lambda \mathrm{C}$ and h-cpx) showed significantly better foamability and foam stability compared to WPI- $\lambda$ C. Results of rheological properties suggested that higher elasticity and viscous films were produced in h- 
$\mathrm{cpx}$ and $\mathrm{pWPI}-\lambda \mathrm{C}$ systems corresponding to better foam stability. Heat treatment applied in pWPI- $\lambda \mathrm{C}$ and $\mathrm{h}-\mathrm{cpx}$ systems led to the change of the secondary structure and tertiary structure of proteins, thus promoted the protein-protein interactions, leading to better foaming properties. Heating WPI and $\lambda C$ together to form heated soluble complex resulted in thicker and viscoelastic interfacial film surrounding the air bubbles and thus better foam stability. Foam microstructure images indicated that foams produced from $\mathrm{h}$-cpx had thicker film surrounding the air bubbles, and consisted of smaller initial bubble area, more uniformed bubble size and slower destabilized. Microstructure analysis results also supported that h-cpx foams were more stable. To further confirm that stronger interactions between WPI and $\lambda C$ contributed to the improved foaming properties, the effect of $\mathrm{pH}(6.2,6.5$ and 7.0) was investigated. Electrostatic interactions between the positively charged patches on the proteins and negatively charged polysaccharide at $\mathrm{pH}>\mathrm{pl}$ could increase when $\mathrm{pH}$ is lowered. Foam stability was higher in $\mathrm{h}$-cpx system for all three $\mathrm{pH}$ levels, especially at $\mathrm{pH} 6.2$ where the strongest interactions were formed compared with the other two $\mathrm{pH}$ levels. This study clearly demonstrated that foaming properties of WPI can be enhanced by addition of anionic polysaccharides, such as $\lambda C$. By selecting appropriate concentration and heating conditions, optimum foaming properties can be achieved. 


\section{REFERENCES}

Allen KE, Murray BS, Dickinson E. 2008. Development of a model whipped cream: effects of emulsion droplet liquid/solid character and added hydrocolloid. Food Hydrocolloids 22(4):690-9.

Baeza R, Carrera Sanchez C, Pilosof AMR, Rodríguez Patino JM. 2005. Interactions of polysaccharides with $\beta$-lactoglobulin adsorbed films at the airwater interface. Food Hydrocolloids 19(2):239-48.

Bals A, Kulozik U. 2003a. Effect of pre-heating on the foaming properties of whey protein isolate using a membrane foaming apparatus. International Dairy Journal 13(11):903-8.

Bals A, Kulozik U. 2003b. The influence of the pore size, the foaming temperature and the viscosity of the continuous phase on the properties of foams produced by membrane foaming. Journal of Membrane Science 220(1):5-11.

Berry TK, Yang X, Foegeding EA. 2009. Foams prepared from whey protein isolate and egg white protein: 2. Changes associated with angel food cake functionality. Journal of Food Science 74(5):E269-77.

Borcherding K, Lorenzen PC, Hoffmann W, Schrader K. 2008. Effect of foaming temperature and varying time/temperature-conditions of pre-heating on the foaming properties of skimmed milk. International Dairy Journal 18(4):349-58.

Borcherding K, Lorenzen PC.HR, Hoffmann W. 2009. Effect of protein content, casein-whey protein ratio and $\mathrm{pH}$ value on the foaming properties of skimmed milk. International Journal of Dairy Technology 62(2):161-9.

Campbell G, Mougeot E. 1999. Creation and characterization of aerated food products. Trends in Food \& Technology 10:283-96.

Carp D, Bartholomai G, Relkin P, Pilosof A. 2001. Effects of denaturation on soy protein-xanthan interactions: comparison of a whipping-rheological and a bubbling method. Colloids and Surfaces B: Biointerfaces 21(1):163-71.

Carp DJ, Baeza RI, Bartholomai GB, Pilosof AMR. 2004. Impact of proteins-Kcarrageenan interactions on foam properties. LWT-Food Science and Technology 37(5):573-80.

Carrier V, Colin A. 2003. Coalescence in draining foam. Langmuir: the ACS journal of surfaces and colloids 19(11):4. 
Clark DC, Wilde PJ, Marion D. 1994. The protection of beer foam against lipidinduced destabilization. Journal of the Institute of Brewing 100(1):23-6.

Campbell G, Mougeot E. 1999. Creation and characterisation of aerated food products. Trends in Food \& Technology 10:283-96.

Cohen-Addad S, Hoballah H, Ouml HR. 1998. Viscoelastic response of a coarsening foam. Phys Rev E 57(6):6897-901.

Damodaran S. 2005. Protein stabilization of emulsions and foams. Journal of Food Science 70:R54-64.

Damodaran S, Paraf A. 1997. Protein-stabilized Foams and Emulsions. In: Damodaran S. and Paraf A., editors. Food proteins and their applications. New York: CRC Press. p 57-105.

Davis JP, Foegeding EA. 2004. Foaming and interfacial properties of polymerized whey protein isolate. Journal of Food Science 69: C404-10.

Davis JP, Foegeding EA. 2007. Comparisons of the foaming and interfacial properties of whey protein isolate and egg white proteins. Colloids and Surfaces B: Biointerfaces 54(2):200-10.

Davis JP, Foegeding EA, Hansen FK. 2004. Electrostatic effects on the yield stress of whey protein isolate foams. Colloids and Surfaces B: Biointerfaces 34(1):13-23.

De Jong S, Klok HJ, Van de Velde F. 2009. The mechanism behind microstructure formation in mixed whey protein-polysaccharide cold-set gels. Food Hydrocolloids 23(3):755-64.

De la Fuente M, Hemar Y, Singh H. 2004. Influence of K-carrageenan on the aggregation behaviour of proteins in heated whey protein isolate solutions. Food Chemistry 86(1):1-9.

Dickinson E. 1992. Foams. In: Dickinson E. editor. An Introduction to Food Colloids. New York: Oxford University Press. p 123-137.

Dickinson E. 2003. Hydrocolloids at interfaces and the influence on the properties of dispersed systems. Food Hydrocolloids 17:25-39.

Dickinson E. 2008. Interfacial structure and stability of food emulsions as affected by protein-polysaccharide interactions. Soft Matter 4(5):932-42.

Dubreil L, Compoint JP, Marion D. 1997. Interaction of puroindolines with wheat flour polar lipids determines their foaming properties. Journal of Agricultural and Food Chemistry 45(1):108-16. 
Dutta A, Chengara A, Nikolov AD, Wasan DT, Chen K, Champbell B. 2004. Destabilization of aerated food products: effects of Oswald ripening and gas diffusion Journal of Food Engineering 62: 177-184.

Engelhardt K, Lexis M, Gochev G, Konnerth C, Miller R, Willenbacher N, Peukert W, Braunschweig B. 2013. pH effects on the molecular structure of betalactoglobulin modified air-water interfaces and its impact on foam rheology. Langmuir: the ACS Jounal of Surfaces and Colloids 29(37):11646-55.

ErÇElebi EA, IbanoĞLu E. 2009. Effects of ionic strength on the foaming properties of whey protein isolate and egg white in the presence of polysaccharides. Journal of Food Processing and Preservation 33(4):513-26.

Etoc A, Delvigne F, Lecomte JP, Thonart P. 2006. Foam control in fernatation bioprocess. Applied Biochemistry and Biotechnology 129(132):392-404.

Exerova D, Kryglyakov P. 1998. Foam drainage. In: Exerova DR. Kryglyakov PM. editors. Foam and foam films: teory, experiment, application. New York: Elsevier. p 381-446.

Foegeding EA, Davis JP, Doucet D, McGuffey MK. 2002. Advances in modifying and understanding whey protein functionality. Trends in Food \& Technology 13:151-9.

Foegeding EA, Luck P, Davis J. 2006. Factors determining the physical properties of protein foams. Food Hydrocolloids 20(2):284-92.

Gennes P-Gd, Francoise B-W, David Q. 2004. Capillarity: deformable interfaces. In: Gennes P-Gd, Francoise B-W, David Q., editors. Capillarity and wetting phenomena: drops, bubbles, pearls,waves. New York: Springer. p 1-13.

Hagolle N, Relkin P, Popineau Y, Bertrand D. 2000. Study of the stability of egg white protein-based foams: effect of heating protein solution. Journal of the Science of Food and Agriculture 80(8):1245-52.

Hailing PJ, Walstra P. 1981. Protein-stabilized foams and emulsions. Critical Reviews in Food Science \& Nutrition 15(2):155-203.

Hanaor D, Michelazzi M, Leonelli C, Sorrell CC. 2012. The effects of carboxylic acids on the aqueous dispersion and electrophoretic deposition of $\mathrm{ZrO}$. Journal of the European Ceramic Society 32(1):235-44.

Herceg Z, Režek A, Lelas V, Krešić G, Franetović M. 2007. Effect of carbohydrates on the emulsifying, foaming and freezing properties of whey protein suspensions. Journal of Food Engineering 79(1):279-86.

Herzhaft B. 1999. Rheology of aqueous foams: a literature review of some experimental works. Oil \& Gas Science and Technology 54(5):587-96. 
Höhler R, Cohen-Addad S. 2005. Rheology of liquid foam. Journal of Physics: Condensed Matter 17(41):R1041-69.

Hunter RJ. 1981. Introduction. In: Hunter RJ. editor. Zeta potential in colloid science: principles and applications: San Diego: Academic Press. p 1-10.

Huppertz T. 2010. Foaming properties of milk: A review of the influence of composition and processing. International Journal of Dairy Technology 63(4):477-88.

Jimenez-Junca CA, Gumy JC, Sher A, Niranjan K. 2011. Rheology of milk foams produced by steam injection. Journal of Food Science 76(9):E569-75.

Kamath S, Huppertz T, Houlihan AV, Deeth HC. 2008. The influence of temperature on the foaming of milk. International Dairy Journal 18(10-11):9941002.

Lee Y-H. 1992. Food-processing approaches to altering allergenic potential of milk-based formula. Journal of Pediatrics 121(5):S47-50.

Luck PJ, Bray N, Foegeding EA. 2002. Factors determining yield stress and overrun of whey protein foams. Journal of Food Science 67:1677-81.

Martin AH, Grolle K, Bos MA, Stuart MAC, Van Vliet T. 2002. Network forming properties of various proteins adsorbed at the air/water interface in relation to foam stability. Journal of Colloid Interface Science 254(1):175-83.

Martínez KD, Ganesan V, Pilosof AM, Harte FM. 2011. Effect of dynamic highpressure treatment on the interfacial and foaming properties of soy protein isolate-hydroxypropylmethylcelluloses systems. Food Hydrocolloids 25(6):1640-5.

Miquelim JN, Lannes S, Mezzenga R. 2010. pH Influence on the stability of foams with protein-polysaccharide complexes at their interfaces. Food Hydrocolloids 24(4):398-405.

Mishra S, Mann B, Joshi V. 2001. Functional improvement of whey protein concentrate on interaction with pectin. Food Hydrocolloids 15(1):9-15.

Mott CL, Hettiarachchy NS, Qi M. 1999. Effect of xanthan gum on enhancing the foaming properties of whey protein isolate. JAOCS 76(11):1383-6.

Murray B. 2007. Stabilization of bubbles and foams. Current Opinion in Colloid \& Interface Science 12:232-41.

Narchi I, Vial C, Djelveh G. 2009. Effect of protein-polysaccharide mixtures on the continuous manufacturing of foamed food products. Food Hydrocolloids 23(1):188-201. 
Nicorescu I, Loisel C, Riaublanc A, Vial C, Djelveh G, Cuvelier G, Legrand J. 2009. Effect of dynamic heat treatment on the physical properties of whey protein foams. Food Hydrocolloids 23(4):1209-19.

Nicorescu I, Vial C, Loisel C, Riaublanc A, Djelveh G, Cuvelier G, Legrand J. 2010. Influence of protein heat treatment on the continuous production of food foams. Food Research International 43(6):1585-93.

Patino JMR, Pilosof AM. 2011. Protein-polysaccharide interactions at fluid interfaces. Food Hydrocolloids 25(8):1925-37.

Perez AA, Carrara CR, Sánchez CC, Santiago LG, Rodríguez Patino JM. 2009a. Interfacial and foaming characteristics of milk whey protein and polysaccharide mixed systems. AIChE Journal 56(4):1007-1017.

Perez AA, Carrara CR, Sánchez CC, Santiago LG, Rodríguez Patino JM. $2009 \mathrm{~b}$. Interfacial dynamic properties of whey protein concentrate/polysaccharide mixtures at neutral pH. Food Hydrocolloids 23(5):1253-62.

Perez AA, Sánchez CC, Patino JM, Rubiolo AC, Santiago LG. 2010. Milk whey proteins and xanthan gum interactions in solution and at the air-water interface: a rheokinetic study. Colloids Surfaces B: Biointerfaces 81(1):50-7.

Perez AA, Sánchez CC, Rodríguez Patino JM, Rubiolo AC, Santiago LG. 2012. Effect of enzymatic hydrolysis and polysaccharide addition on the $\beta$-lactoglobulin adsorption at the air-water interface. Journal of Food Engineering 109(4):712-20.

Pernell C, Foegeding E, Luck P, Davis J. 2002. Properties of whey and egg white protein foams. Colloids and Surfaces A: Physicochemical and Engineering Aspects 204(1):9-21.

Phillips L, Haque Z, Kinsella J. 1987. A method for the measurement of foam formation and stability. Journal of Food Science 52(4):1074-7.

Phillips L, Yang S, Kinsella J. 2006. Neutral salt effects on stability of whey protein isolate foams. Journal of Food Science 56(2):588-9.

Phillips L, Yang S, Schulman W, Kinsella J. 2008. Effects of lysozyme, clupeine, and sucrose on the foaming properties of whey protein isolate and $\beta$-lactoglobulin. Journal of Food Science 54(3):743-7.

Phillips LG, Schulman W, Kinsella JE. 1990. pH and heat treatment effects on foaming of whey protein isolate. Journal of Food Science 55:1116-9.

Prud'homme RK, Khan SA. 1995. Structure, drainage, and coalescence of foams and concentrated emulsions. In: Prud'homme RK. Khan SA. editors. Foams: Theory, Measurements, and Applications. New York: Marcel Dekker. p 99-188. 
Raikos V, Campbell L, Euston S. 2007. Effects of sucrose and sodium chloride on foaming properties of egg white proteins. Food Research International 40:347-54.

Rouyer F, Cohen-Addad S, Höhler R. 2005. Is the yield stress of aqueous foam a well-defined quantity? Colloids and Surfaces A: Physicochemical and Engineering Aspects 263(1-3):111-6.

Rullier B, Novales B, Axelos MAV. 2008. Effect of protein aggregates on foaming properties of $\beta$-lactoglobulin. Colloids and Surfaces A: Physicochemical and Engineering Aspects 330(2-3):96-102.

Salminen H, Weiss J. 2013. Effect of pectin type on association and pH stability of whey protein-pectin complexes. Food Biophysics. http://dx.doi.org/10.1007/s11483-013-9314-3.

Sarma Dshsr KK. 1988. Effecis of intial gas volume fraction on stability of aqueous air foams. Ind Eng Chem Res 27:892-4.

Schmitt C, Palma da Silva T, Bovay C, Rami-Shojaei S, Frossard P, Kolodziejczyk E, Leser ME. 2005. Effect of time on the interfacial and foaming properties of $\beta$-lactoglobulin/acacia gum electrostatic complexes and coacervates at $\mathrm{pH}$ 4.2. Langmuir: the ACS Jounal of Surfaces and Colloids 21(17):7786-95.

Schmitt C, Turgeon SL. 2011. Protein/polysaccharide complexes and coacervates in food systems. Adv Colloid Interface Sci 167(1):63-70.

Seguineau De Preval E, Fabrice D, Gilles M, Gérard C, Samir M. 2013. Influence of surface properties and bulk viscosity on bubble size prediction during foaming operation. Colloids and Surfaces A: Physicochemical and Engineering Aspects. http://dx.doi.org/10.1016/j.colsurfa.2013.05.025.

Silva S, Espiga A, Niranjan K, Livings S, Gumy J-C, Sher A. 2008. Formation and stability of milk foams. Bubbles in Food 2:153-61.

Tamm F, Sauer G, Scampicchio M, Drusch S. 2012. Pendant drop tensiometry for the evaluation of the foaming properties of milk-derived proteins. Food Hydrocolloids 27(2):371-7.

Vardhanabhuti B, Foegeding E. 2008. Effects of dextran sulfate, $\mathrm{NaCl}$, and initial protein concentration on thermal stability of $\beta$-lactoglobulin and $\alpha$-lactalbumin at neutral pH. Food Hydrocolloids 22(5):752-62.

Vardhanabhuti B, Yucel U, Coupland JN, Foegeding EA. 2009. Interactions between $\beta$-lactoglobulin and dextran sulfate at near neutral $\mathrm{pH}$ and their effect on thermal stability. Food Hydrocolloids 23(6):1511-20. 
Walstra P. 2003. Formation of emulsions and foams. In: Walstra P. editor. Physical Chemistry of Foods. New York: Marcel Dekker. p 355-90.

Weinbreck F, Nieuwenhuijse H, Robijn GW, de Kruif CG. 2004. Complexation of whey proteins with carrageenan. Journal of Agricultural and Food Chemistry. 52(11):3550-5.

Wierenga PA, Gruppen H. 2010. New views on foams from protein solutions. Current Opinion in Colloid \& Interface Science 15(5):365-73.

Wilde P. 2000a. Interfaces: their role in foam and emulsion behavior. Current Opinion in Colloid \& Interface Science 5(3):176-81.

Wilde P. 2000b. Interfaces: their role in foam and emulsion behaviour. Current Opinion in Colloid \& Interface Science 5(3):176-81.

Yang X, Foegeding EA. 2011. The stability and physical properties of egg white and whey protein foams explained based on microstructure and interfacial properties. Food Hydrocolloids 25(7):1687-701.

Ye A. 2008. Complexation between milk proteins and polysaccharides via electrostatic interaction: principles and applications-a review. International Journal of Food Science \& Technology 43(3):406-15.

Zayas JF. 1997. Foaming properties of proteins. Functionality of Proteins in Food:260-309.

Zhang S, Hsieh F-H, Vardhanabhuti B. 2013. Acid-induced gelation properties of heated whey protein- pectin soluble complex (Part I): Effect of initial pH. Food Hydrocolloids. http://dx.doi.org/10.1016/j.foodhyd.2013.07.029.

Zhang S, Zhang Z, Lin M, Vardhanabhuti B. 2012. Raman spectroscopic characterization of structural changes in heated whey protein isolate upon soluble complex formation with pectin at near neutral $\mathrm{pH}$. Journal of Agricultural and Food Chemistry. 60(48):12029-35.

Zhang Z, Dalgleish D, Goff H. 2004. Effect of pH and ionic strength on competitive protein adsorption to air/water interfaces in aqueous foams made with mixed milk proteins. Colloids and Surfaces B: Biointerfaces 34(2):113-21.

Zhu H, Damodaran S. 1994. Effects of calcium and magnesium ions on aggregation of whey protein isolate and its effect on foaming properties. Journal of Agricultural and Food Chemistry. 42:856-62.

Zhu H, Damodaran, S. 1994. Heat-induced conformational changes in whey protein isolate and its relation to foaming properties. Journal of Agricultural and Food Chemistry 42:846-55. 
APPENDIX 
Table 1. Foaming properties of $5 \%$ egg white protein (EWP) at $\mathrm{pH} 7$.

\begin{tabular}{ccc}
\hline Treatment & Overrun (\%) & Drainage 1/5 life (min) \\
\hline EWP & $1266.1 \pm 65.5$ & $63 \pm 1$ \\
\hline
\end{tabular}


Table 2. Raw data of foaming properties of WPI- $\lambda \mathrm{C}$ mixed systems with different $\lambda \mathrm{C}$ at different $\mathrm{pH}$.

\begin{tabular}{ccccccc}
\hline \multirow{2}{*}{ System } & $\mathrm{pH}$ & $\begin{array}{c}\lambda C \\
\text { concentration } \\
(\%)\end{array}$ & \multicolumn{2}{c}{ Overrun (\%) } & \multicolumn{2}{c}{$\begin{array}{c}\text { Drainage 1/5 life } \\
(\mathrm{min})\end{array}$} \\
\cline { 5 - 7 } & & & Rep.1 & Rep. 2 & Rep.1 & Rep. 2 \\
\hline WPI- $\lambda \mathrm{C}$ & 7.0 & 0.00 & $\mathrm{NA}$ & $\mathrm{NA}$ & & $\mathrm{NA}$ \\
& & & & & $\mathrm{NA}$ & \\
& & 0.05 & 901 & 922 & 40 & 36 \\
& & 0.15 & 1337 & 1298 & 59 & 61 \\
& & 0.25 & 1236 & 1190 & 86 & 82 \\
& 6.5 & 0.25 & 1275 & 1278 & 107 & 104 \\
& 6.2 & 0.25 & 1331 & 1315 & 119 & 117 \\
\hline $\mathrm{pWPI}-\lambda \mathrm{C}$ & 7.0 & 0.00 & 1052 & 962 & 31 & 31 \\
& & 0.05 & 1690 & 1694 & 56 & 57 \\
& & 0.15 & 1666 & 1670 & 80 & 80 \\
& & 0.25 & 1356 & 1392 & 110 & 114 \\
& 6.5 & 0.25 & 1398 & 1415 & 127 & 121 \\
& 6.2 & 0.25 & 965 & 984 & 158 & 148 \\
\hline $\mathrm{h}-\mathrm{cpx}$ & 7.0 & 0.00 & 1052 & 962 & 31 & 31 \\
& & 0.05 & 1526 & 1596 & 58 & 55 \\
& & 0.15 & 1555 & 1561 & 86 & 88 \\
& & 0.25 & 1369 & 1372 & 143 & 133 \\
& 6.5 & 0.25 & 1296 & 1291 & 135 & 139 \\
& 6.2 & 0.25 & 982 & 901 & 203 & 199 \\
\hline
\end{tabular}

